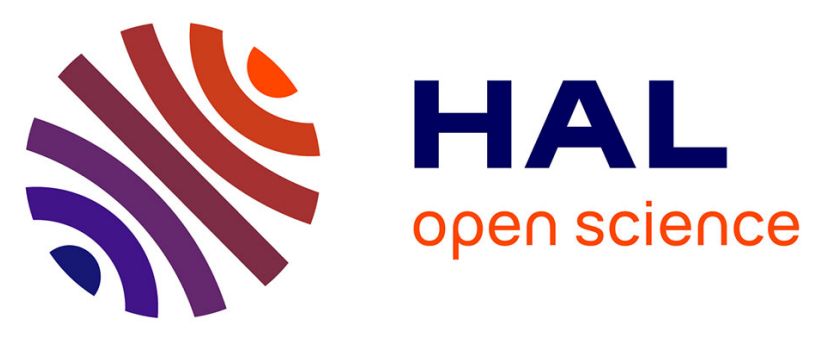

\title{
Elucidating the dechlorination mechanism of hexachloroethane by Pd-doped zerovalent iron microparticles in dissolved lactic acid polymers using chromatography and indirect monitoring of iron corrosion
}

Romain Rodrigues, Stéphanie Betelu, Stefan Colombano, Guillaume Masselot, Théodore Tzedakis, Ioannis Ignatiadis

\section{- To cite this version:}

Romain Rodrigues, Stéphanie Betelu, Stefan Colombano, Guillaume Masselot, Théodore Tzedakis, et al.. Elucidating the dechlorination mechanism of hexachloroethane by Pd-doped zerovalent iron microparticles in dissolved lactic acid polymers using chromatography and indirect monitoring of iron corrosion. Environmental Science and Pollution Research, 2019, 26, pp.7177-7194. 10.1007/s11356019-04128-y . hal-02380709

\author{
HAL Id: hal-02380709 \\ https://hal.science/hal-02380709
}

Submitted on 15 May 2020

HAL is a multi-disciplinary open access archive for the deposit and dissemination of scientific research documents, whether they are published or not. The documents may come from teaching and research institutions in France or abroad, or from public or private research centers.
L'archive ouverte pluridisciplinaire HAL, est destinée au dépôt et à la diffusion de documents scientifiques de niveau recherche, publiés ou non, émanant des établissements d'enseignement et de recherche français ou étrangers, des laboratoires publics ou privés. 
$1 \quad$ Elucidating the dechlorination mechanism of hexachloroethane by Pd-doped zero-valent iron microparticles in dissolved lactic acid polymers using

4 Romain Rodrigues ${ }^{1,2,3^{*}}$, Stéphanie Betelu ${ }^{1}$, Stéfan Colombano ${ }^{1}$, Guillaume Masselot ${ }^{2}$, Theodore Tzedakis ${ }^{3}$,

5 Ioannis Ignatiadis ${ }^{1}$

6 1: BRGM (French Geological Survey), 3 avenue Claude Guillemin, 45060 Orléans Cedex 2, France.

7 2: ADEME (French Environment and Energy Management Agency), 20 avenue du Grésillé, 49000 Angers

8 Cedex 1, France.

9 3: LGC (Chemical Engineering Laboratory), 118 route de Narbonne, 31062 Toulouse Cedex 9, France.

$10 *$ Corresponding author: romain.rodrigues64@gmail.com 
The degradation mechanism of the pollutant hexachloroethane (HCA) by a suspension of Pd-doped zero-valent iron microparticles (Pd-mZVI) in dissolved lactic acid polymers and oligomers (referred to as PLA), was investigated using gas chromatography and the indirect monitoring of iron corrosion by continuous measurements of $\mathrm{pH}$, oxidation-reduction potential (ORP) and conductivity. The first experiments took place in the absence of HCA, to understand the evolution of the $\mathrm{Pd}-\mathrm{mZVI} / \mathrm{PLA} / \mathrm{H}_{2} \mathrm{O}$ system. This showed that the evolution of $\mathrm{pH}$, ORP and conductivity is related to changes in solution chemistry due to iron corrosion, and that the system is initially cathodically controlled by $\mathrm{H}^{+}$mass transport to Pd surfaces because of the presence of an extensive PLA layer. We then investigated the effects of Pd-mZVI particles, temperature, initial HCA concentration and PLA content on the Pd-mZVI/PLA/HCA/ $\mathrm{H}_{2} \mathrm{O}$ system, to obtain a better understanding of the degradation mechanism. In all cases, HCA dechlorination first requires the production of atomic hydrogen $\mathrm{H}^{*}-$ involving the accumulation of tetrachloroethylene (PCE) as an intermediate-before its subsequent reduction to non-chlorinated $\mathrm{C}_{2}$ and $\mathrm{C}_{4}$ compounds. The ratio between Pd-mZVI dosage, initial HCA concentration and PLA content affects the rate of $\mathrm{H}^{*}$ generation as well as the rate-determining step of the process. A pseudo-first-order equation can be applied when Pd-mZVI dosage is much higher than the theoretical stoichiometry (600 mg for $[\mathrm{HCA}]_{0}=5-20 \mathrm{mg} \mathrm{L}^{-1}$ ). Our results indicate that the HCA degradation mechanism includes mass transfer, sorption, surface reaction with $\mathrm{H}^{*}$, and desorption of the product.

\section{Keywords}

Hexachloroethane; Pd/Fe microparticles; Iron corrosion; Physical and chemical monitoring; Dechlorination mechanism; Lactic acid polymers

\section{Introduction}

Since the first application of zero-valent iron (ZVI) as granular particles in permeable reactive barriers (PRBs) for in situ remediation of contaminated groundwater in the 1990s (Gillham and O'Hannesin 1994; O'Hannesin and Gillham 1998), ZVI has been the subject of widespread research to improve the reactivity, stability and transport of such particles in the subsurface environment (Zhang 2003; Crane and Scott 2012; O 'Carroll et al. 2013; Yan et al. 2013; Tosco et al. 2014; Liu et al. 2014b; Fu et al. 2014; Zhao et al. 2016; Reddy et al. 2016; Stefaniuk et al. 2016; Sun et al. 2016; Mu et al. 2017). The use of microscale ZVI (mZVI) particles appears to be a sustainable option, as they are less expensive and less bactericidal, and have a longer life in field experiments 
than nanoscale ZVI (nZVI) particles (Lee et al. 2008; Comba et al. 2011; Noubactep et al. 2012; Velimirovic et al. 2012, 2013a, 2018). However, irrespective of their size, iron particles have a low electron efficiency toward contaminants and react mainly with water to produce $\mathrm{Fe}^{2+}$ and $\mathrm{H}_{2}$ (Schöftner et al. 2015; Fan et al. 2016; Tang et al. 2017b). It was realized that bimetallic particles, especially Pd-ZVI ones, can be used to increase the degradation rate by taking advantage of the hydrogenation reactions that generate atomic hydrogen $\mathrm{H}^{*}$ on the second metal (Lowry and Reinhard 1999; Kim and Carraway 2003; Lien and Zhang 2007; Xie and Cwiertny 2013; Liu et al. 2014b). Finally, the use of a polymeric coating is essential for improving the stability, dispersion and transport of the particles in groundwater (He et al. 2007; Phenrat et al. 2008; Kaifas et al. 2014; Kocur et al. 2014; Reddy et al. 2014; Han et al. 2016; Kumar et al. 2017; Fang et al. 2018).

Despite these improvements, the exact mechanism of contaminant removal by iron-based particles still remains unclear. The particles have a core-shell structure, with an $\mathrm{Fe}^{0}$-core encapsulated by a thin, defective and semiconducting shell of mixed-valence $\mathrm{Fe}_{\mathrm{x}} \mathrm{O}_{\mathrm{y}}$ iron oxides (Martin et al. 2008; Filip et al. 2014; Liu and Zhang 2014; Ling et al. 2017; Bae et al. 2018). This shell is known to be the seat of all contaminant remediation processes through a combination of adsorption, reduction and co-precipitation processes (Noubactep 2008). For bimetallic particles, the presence of the second metal results in the formation of galvanic cells, Fe acting as an anode and preferentially oxidized and the second metal acting as the main cathodic site (Grittini et al. 1995; Lien and Zhang 1999), which implies that the reduction process occurs mainly on its surface. In both cases, the growth and structural evolution of the shell with time in the $\mathrm{ZVI} / \mathrm{H}_{2} \mathrm{O}$ system —also known as aging — generally results in a decrease of its porosity and electrical conductivity (Mu et al. 2017) and in the entrapment of the second metal (Yan et al. 2010; Ling and Zhang 2014), affecting the kinetics of iron oxidation and thus all degradation processes (Kumar et al. 2014; Liu et al. 2017). Understanding the evolution of ZVI particles and its impact on the solution chemistry is therefore crucial for evaluating their reactivity, fate and other effects.

Direct characterization methods, such as microscopic and spectroscopic techniques or total-iron measurements (Nurmi et al. 2005; Sun et al. 2006; Sarathy et al. 2008; Baer et al. 2008), require the recovery of solids and sample stabilization, which can be hardly feasible in the field. Such techniques are useful for characterizing the structural evolution of the iron-oxide shell, but they do not provide direct quantitative evidence of iron corrosion. Corrosion rates are commonly estimated by indirect characterization methods, especially hydrogen production measurements (Liu and Lowry 2006; Velimirovic et al. 2014), but this method is unsuitable for Pd-ZVI particles as hydrogen sorption occurs on the Pd surface (Chaplin et al. 2012). Other indirect methods focus on changes in the solution chemistry, e.g. pH and oxidation-reduction potential (ORP), due to the addition of ZVI particles and 
the resulting reactions in the $\mathrm{ZVI} / \mathrm{H}_{2} \mathrm{O}$ system ( $\mathrm{Yu}$ et al. 2014). In field applications, though the complex water chemistry can alter the individual characterization ability of these methods, such indirect methods can show up evidence for ZVI-impacted zones due to the transport of iron-corrosion products, with their associated changes in biogeochemical conditions (Elliott and Zhang 2001; He et al. 2010; Wei et al. 2010, 2012, Shi et al. 2011, 2015; Kocur et al. 2014). The combined use of probes appears therefore as an effective tool for understanding both the reactivity and fate of iron-based particles over short- and long-term time scales (Grieger et al. 2010; Shi et al. 2015).

In our previous study, we showed that the use of continuous $\mathrm{pH}$ and ORP measurements was effective in laboratory experiments for characterizing the degradation mechanism of hexachlorobutadiene (HCBD) by Pddoped ZVI microparticles (noted Pd-mZVI) suspended in dissolved lactic acid polymers and oligomers (referred to as PLA) (Rodrigues et al. 2017a). PLA is a low-cost biodegradable polymer, widely used for the denitrification of water (Wang and Chu 2016), which we selected as surface modifier to (i) Increase the viscosity of the suspension for preventing aggregation, (ii) Provide hydrophobicity on the particle surface for improving the contact with the hydrophobic pollutant, and (iii) Create acidic conditions through PLA hydrolysis and the release of organic acids for obtaining optimal conditions for the reductive dechlorination of highly chlorinated organic compounds. In addition, in field experiments, PLA acts as a slow-release source of carbon and hydrogen that can stimulate biodegradation by organohalide-respiring bacteria, to maintain reductive conditions over the long term. The efficiency of polyesters, such as polyhydroxyalkanoates (PHA), has already been proven for the bioremediation of COCs (Aulenta et al. 2008; Pierro et al. 2017). The use of ZVI-based particles with a biodegradable slow-release carbon and hydrogen source appears thus as a sustainable strategy for creating an in situ reactive zone for pollution treatment. It combines the reactivity of a short-term chemical treatmentespecially for highly chlorinated and recalcitrant contaminants-with maintaining reductive conditions for longterm bioremediation, in order to prevent a potential rebound effect after the aging of iron-based particles (Baric et al. 2012; Bruton et al. 2015; Koenig et al. 2016; Kocur et al. 2016; Chronopoulou et al. 2016; Xu et al. 2017; Herrero et al. 2019).

The objective of our study was to elucidate the degradation mechanism of hexachloroethane ( $\left.\mathrm{HCA}, \mathrm{C}_{2} \mathrm{Cl}_{6}\right)$ using Pd-mZVI in PLA, through the indirect monitoring of iron corrosion and its associated changes in solution chemistry by means of continuous measurements of $\mathrm{pH}$, ORP and conductivity. HCA is a common highly chlorinated pollutant found in soil and groundwater, with a low aqueous solubility (Rodrigues et al. 2017b). It is mainly used in the production of pyrotechnic devices and metal alloys, but it can also be a by-product of 
fabricating lower chlorination products (Stringer and Johnston 2001). Though HCA is known to be relatively persistent in the environment (Howard 1989), it can undergo reductive dechlorination (Butler and Hayes 1998; Patterson et al. 2001; Lien and Zhang 2005; Song and Carraway 2005; Wu et al. 2014; Zhu et al. 2018). Many chlorinated intermediates can accumulate during this transformation, especially chlorinated ethanes, ethylenes and acetylenes, some of them (TCE and vinyl chloride) being classified as human carcinogens by IARC.

Understanding the HCA degradation mechanism is therefore important for preventing any accumulation of toxic byproducts. Experiments were first done in the absence of HCA for evaluating any changes in the PdmZVI/PLA/ $\mathrm{H}_{2} \mathrm{O}$ system. We then investigated the effects of Pd-mZVI particles, temperature, initial HCA concentration and PLA content on the Pd-mZVI/PLA/HCA/ $\mathrm{H}_{2} \mathrm{O}$ system, to provide a better insight into the degradation mechanism.

\section{Materials and methods}

\subsection{Chemicals}

HCA (99\%) and tetrachloroethylene (PCE, 99\%) were purchased from Sigma-Aldrich. A mix of chlorinated hydrocarbons in methanol $\left(200 \mu \mathrm{g} \mathrm{mL}^{-1}\right)$ containing chlorinated ethanes and ethylenes was obtained from Sigma-Aldrich for the preparation of standard solutions (EPA 502/524.2 VOC Mix). Stock solutions of HCA (5, 10 and $20 \mathrm{~g} \mathrm{~L}^{-1}$ ) were prepared in HPLC-grade methanol, supplied by VWR. Deionized water was obtained from a Milli-Q water system $(18.2 \mathrm{M} \Omega \mathrm{cm})$ and was degassed before any experiment with an ultrasonic bath at $45 \mathrm{kHz}$, followed by $\mathrm{N}_{2}$ flushing during the preparation of batch experiments to limit the introduction of $\mathrm{O}_{2}$.

The-partially biologically produced-Pd-doped iron microparticles (BioCAT, noted as Pd-mZVI) and the mixture of lactic acid polymers and oligomers dissolved in ethyl lactate (Dechlorem, noted as PLA) were provided by Biorem Engineering. According to the manufacturer, the particles are smaller than $10 \mu \mathrm{m}$ with an average size of 3-5 $\mu \mathrm{m}$, palladium representing 0.1-2 wt $\%$ of the particles. The specific surface area, measured with the BET-N $\mathrm{N}_{2}$ adsorption method (BELSORP-max, MicrotracBEL, Japan), was less than $1 \mathrm{~m}^{2} \mathrm{~g}^{-1}$. The suspension of Pd-mZVI in PLA was prepared before any experiments by manual mixing of the corresponding amounts of PLA and Pd-mZVI.

For the system without HCA, the experiments were also performed with nZVI particles (NANOFER STAR, obtained from Nano Iron), and the results are presented in the Supplementary data. 


\subsection{Batch experiments}

127 Batch experiments were conducted in a $1 \mathrm{~L}$ cylindrical Pyrex double-walled water-jacketed reactor, equipped with a mechanical-propeller stirring rod (at $300 \mathrm{rpm}$ ). The reactor head has hermetic ports for installing the electrodes, for the introduction of the reactant and for sampling. $1 \mathrm{~mL}$ of the appropriate stock solution was injected into the reactor filled with degassed deionized water with initial zero-headspace conditions. Reaction was initiated by introducing the Pd-mZVI suspension in PLA, and $3 \mathrm{~mL}$ aliquots were collected at selected times. The reduction was stopped by separating the particles with powerful magnets. $1 \mathrm{~mL}$ of the supernatant aqueous phase without particles was collected and diluted (1:10) with degassed pure water into $20 \mathrm{~mL}$ headspace vials equipped with a PTFE septum. The prepared samples were finally stocked at $4{ }^{\circ} \mathrm{C}$ and analysed within 24 hours.

\subsection{Analytical methods}

137

The bimetallic microparticles were characterized before any reaction by scanning electron microscopy coupled to energy dispersive X-ray spectrometry (SEM/EDS), X-ray diffraction (XRD) and X-ray photoelectron spectroscopy (XPS). SEM/EDS images were obtained with a Phenom XL microscope (Fondis Bioritech) operating at $15 \mathrm{kV}$. XRD analyses were performed with a D8 Advance diffractometer (Bruker) with a CuK $\alpha$ source $(\lambda=1.5406 \AA)$ at an accelerating voltage of $40 \mathrm{kV}$ and emission current of $40 \mathrm{~mA}$. Samples were scans from 4 to $90^{\circ} 2 \theta$ at $0.03^{\circ} 2 \theta \mathrm{s}^{-1}$. XPS analyses were performed with a K-Alpha+ spectrometer (ThermoFisher Scientific) equipped with a $\mathrm{Al}$ anode generating $\mathrm{Al} \mathrm{K} \mathrm{K}_{\alpha} \mathrm{X}$-ray radiation. Samples were analysed at Fe 2p, Pd 3d, $\mathrm{C} 1 \mathrm{~s}, \mathrm{O} 1 \mathrm{~s}, \mathrm{~N} 1 \mathrm{~s}$ and $\mathrm{Si} 2 \mathrm{p}$ regions after survey scans.

Analysis of HCA and its degradation products was performed by gas chromatography (GC/FID) using a Varian CP-3800 equipped with a DB-624 column (30 m x 0.32 i.d., with a $1.80 \mu \mathrm{m}$ film thickness). Helium was chosen as carrier gas at a $1.2 \mathrm{~mL} \mathrm{~min}^{-1}$ flowrate. Samples were heated at $80{ }^{\circ} \mathrm{C}$ for $30 \mathrm{~min}$, and $200 \mu \mathrm{L}$ of the headspace gas was withdrawn by a gas-tight syringe and introduced in the injector chamber at $250{ }^{\circ} \mathrm{C}(1: 25$ split ratio). The oven was maintained at $35{ }^{\circ} \mathrm{C}$ for $5 \mathrm{~min}$, and then ramped up to $245{ }^{\circ} \mathrm{C}$ at $10{ }^{\circ} \mathrm{C} \min ^{-1}$ with a hold for 10 min at this final temperature. The FID temperature was maintained at $300{ }^{\circ} \mathrm{C}$, and $\mathrm{He}$ was used as carrier gas at a flowrate of $30 \mathrm{~mL} \mathrm{~min}^{-1}$. Combustion in the FID was carried out with $\mathrm{H}_{2}\left(30 \mathrm{~mL} \mathrm{~min}^{-1}\right)$ and air $\left(300 \mathrm{~mL} \mathrm{~min}^{-1}\right)$.

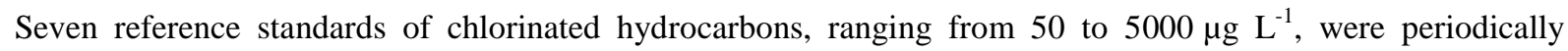
prepared and analysed to ensure the proper quantification of the samples. The qualitative production of nonchlorinated hydrocarbons is also provided in Supplementary data. 
The Pd-mZVI corrosion was monitored by measuring changes in $\mathrm{pH}$, ORP and conductivity with a multiparameter tester (Heitolab MPC 350, Heito) and recorded every $12 \mathrm{~s}$ using a Keithley 2700 data acquisition system controlled via KickStart software. The $\mathrm{pH}$ was measured with a glass electrode (Radiometer Analytical pHC3005-8, Hach), calibrated before each experiment with commercial buffer solutions (pH 7 and 4). The oxidation-reduction potential (ORP) of the solution was measured with a platinum disc electrode (Radiometer Analytical XM150, Hach) with respect to a mercury-mercurous sulphate reference electrode (MMSE, Ametek SI). ORP values were then converted and reported with respect to the standard hydrogen electrode (SHE) by adding $640 \mathrm{mV}$ (saturated $\mathrm{K}_{2} \mathrm{SO}_{4}$ solution). Conductivity was measured with a 2-pole conductivity cell (Tacussel $\mathrm{XE} 150)$ and calibrated before each experiment with a commercial buffer solution $\left(1413 \mu \mathrm{S} \mathrm{cm}^{-1}\right.$ at $\left.25^{\circ} \mathrm{C}\right)$. All electrodes were placed in the aqueous solution at about one third of the reactor.

In a non-buffered system (Bae and Hanna 2015), the evolution of $\mathrm{pH}$ is a good indicator of iron corrosion as $\mathrm{H}^{+}$ is directly implied in the reaction (Eq. 1).

$$
\mathrm{Fe}^{0}+2 \mathrm{H}^{+} \rightarrow \mathrm{Fe}^{2+}+\mathrm{H}_{2}
$$

Eq. (1) is the result of iron oxidation in $\mathrm{Fe}^{2+}$ and $\mathrm{H}^{+}$reduction in $\mathrm{H}_{2}$. The hydrogen evolution reaction (HER) occurs both on the oxide shell and on Pd. Because of the difference in the standard redox potential, $\mathrm{Pd}$ acts as the preferential cathodic site in the system, and the reduction of $\mathrm{H}^{+}$in $\mathrm{H}_{2}$ occurs in a two-step process (Eqs. 2-3).

$$
\begin{gathered}
2 \mathrm{H}^{+}+2 \mathrm{e}^{-\stackrel{\mathrm{Pd}}{\rightarrow}} 2 \mathrm{H}^{*} \\
2 \mathrm{H}^{*} \rightarrow \mathrm{H}_{2} \\
\mathrm{H}^{*}+\mathrm{H}^{+}+\mathrm{e}^{-} \rightarrow \mathrm{H}_{2}
\end{gathered}
$$

The formation of atomic hydrogen $\mathrm{H}^{*}$ on $\mathrm{Pd}$ is of crucial importance as adsorbed $\mathrm{H}^{*}\left(\mathrm{H}_{\text {ads }}^{*}\right)$ is the only active hydrogen species in catalytic hydrodechlorination reactions (Jiang et al. 2017; He et al. 2018; Liu et al. 2018). The cumulative $\mathrm{H}^{+}$consumption, or the total generated $\mathrm{H}^{*}$ yield, can be calculated considering the reduction of $\mathrm{H}^{+}$to $\mathrm{H}^{*}$ and the dissociation of $\mathrm{H}_{2} \mathrm{O}$ into $\mathrm{H}^{+}$before its reduction to $\mathrm{H}^{*}$ (Jiang et al. 2018), as indicated in the Supplementary data (Fig. S3).

Measurements of the oxidation-reduction potential (ORP) provide information on the composition and changes in the physico-chemistry of the solution. In the presence of ZVI particles, ORP values are mainly dependent upon iron-species couples (Shi et al. 2011) and the $\mathrm{H}^{+} / \mathrm{H}_{2}$ redox couple, because of the affinity of Pt (the sensing 

in solution. The conductivity of the solution can be calculated by the equation below (Eq. 4):

$$
\sigma=\sum_{i} \lambda_{i} z_{i} C_{i}
$$

where $\sigma$ is the conductivity $\left(\mathrm{S} \mathrm{m}^{-1}\right), \lambda_{\mathrm{i}}$ the molar ionic conductivity of species $i\left(\mathrm{~S} \mathrm{~m}^{2} \mathrm{~mol}^{-1}\right), z_{\mathrm{i}}$ the electrical charge of species $i$ and $C_{\mathrm{i}}$ the concentration of species $i\left(\mathrm{~mol} \mathrm{~m}^{-3}\right)$. Considering iron corrosion and HCA dechlorination, the main ionic species that can influence the conductivity are $\mathrm{H}^{+}$(at $25{ }^{\circ} \mathrm{C}, \lambda^{\circ}{ }_{\mathrm{H}}^{+}=349.8 \mathrm{~S} \mathrm{~cm}^{2}$ $\left.\mathrm{mol}^{-1}\right), \mathrm{OH}^{-}\left(\lambda^{\circ}{ }_{\mathrm{OH}}^{-}=198 \mathrm{~S} \mathrm{~cm}^{2} \mathrm{~mol}^{-1}\right), \mathrm{Fe}^{2+}\left(\lambda^{\circ}{ }_{1 / 2 \mathrm{Fe}^{2+}}=54 \mathrm{~S} \mathrm{~cm}^{2} \mathrm{~mol}^{-1}\right), \mathrm{Fe}^{3+}\left(\lambda_{1 / 3 \mathrm{Fe}^{\circ}}{ }^{3+}=68 \mathrm{~S} \mathrm{~cm}^{2} \mathrm{~mol}^{-1}\right), \mathrm{Cl}^{-}\left(\lambda^{\circ} \mathrm{Cl}^{-}\right.$ $=76 \mathrm{~S} \mathrm{~cm}^{2} \mathrm{~mol}^{-1}$ ), and the ionic species resulting from the introduction and hydrolysis of PLA. The decrease in $\mathrm{H}^{+}$content due to iron corrosion is responsible for a decrease in conductivity, whereas an increase in the contents of other ionic species causes an increase in conductivity.

\section{Results and discussion}

\subsection{Characterization of Pd-mZVI particles}

The characterization of the Pd-mZVI particles before reaction is shown in Fig. 1 and Fig S1. On Fig. 1a, it is shown that the smallest particles were spherical, with a diameter of 2-3 $\mu \mathrm{m}$. Larger particles with a diameter of about $10 \mu \mathrm{m}$ were also observed (Fig. S1a). On Fig. S1b, the largest particles show the porous structure of the external layer. In addition, EDS analysis reveals that some of the particles have a high carbon content with traces of silicium and phosphorus, which could originate from the biomass used during the bioreductive deposition of palladium nanoparticles (De Windt et al. 2005; Dien et al. 2013).

Fig. $1 \mathrm{~b}$ shows the patterns of the Pd-mZVI particles. The peaks at $44.7^{\circ}, 65.1^{\circ}$ and $82.3^{\circ}$, respectively, can be indexed to the planes (110), (200) and (211) of Fe cubic crystal structure (JCPDS 06-0696), and the peaks at $40.3^{\circ}, 46.9^{\circ}$ and $68.5^{\circ}$, respectively, correspond to the planes (111), (200) and (220) of face centered cubic crystal structure of Pd (the peak at $82.3^{\circ}$ can also be attributed in part to the plane (311)) (JCPDS 46-1043). However, there is no indication of crystalline phases of iron oxide, or only in very small fractions, in contrary to the pattern of nZVI particles for which the diffraction peaks corresponding to magnetite or maghemite were observed (Fig. S2a). Figs 1c, d and e show the XPS spectra of the Pd-mZVI particles. The survey scan from 0 to $1100 \mathrm{eV}$ indicates the presence of $\mathrm{Fe}, \mathrm{Pd}, \mathrm{C}, \mathrm{O}, \mathrm{N}$ and $\mathrm{Si}$ on the surface of the particles (Fig. 2a). As indicated by the low signal intensities between 700 and $730 \mathrm{eV}$ (Fig. 2b), the presence of Fe on the surface of the particles is very limited, in comparison to nZVI particles for which the XPS spectra indicates the presence of metallic iron 
$\left(\mathrm{Fe}^{0}\right)$ and oxidized iron $\left(\mathrm{Fe}^{\mathrm{III}}\right)$ on its surface and near-surface (Fig. S2). The particles present four peaks between 332 and $346 \mathrm{eV}$, named A1, B1, A2 and B2 (Fig. 2c). The two peaks A1 and A2, with binding energies of 335.4 and $340.7 \mathrm{eV}$ respectively, match with the $3 \mathrm{~d}_{5 / 2}$ and $3 \mathrm{~d}_{3 / 2}$ of metallic Pd (Muftikian et al. 1996; Yan et al. 2010), and the two peaks B1 and B2, with binding energies of 338.1 and $343.4 \mathrm{eV}$ respectively, match with the $3 \mathrm{~d}_{5 / 2}$ and $3 d_{3 / 2}$ of oxidized Pd (Voogt et al. 1996). The results indicate that, for Pd-mZVI particles, the core is mainly composed of $\mathrm{Fe}^{0}$, while the external surface of the particles is composed of iron oxides, carbon, silica, and palladium, the latter being required for $\mathrm{H}^{*}$ generation for hydrodechlorination on the surface.

\subsection{Investigation of the $\mathrm{Pd}-\mathrm{mZVI} / \mathrm{PLA} / \mathrm{H}_{2} \mathrm{O}$ system}

Before considering HCA degradation, two experiments were performed without $\mathrm{HCA}$ at $25{ }^{\circ} \mathrm{C}$ in the presence of $600 \mathrm{mg}$ of Pd-mZVI and 850 or $3400 \mathrm{mg}$ of PLA. This was to investigate the influence of PLA on the corrosion kinetics of Pd-mZVI and to understand how to interpret the evolution of pH, ORP and conductivity (Fig. 2).

With $850 \mathrm{mg}$ of PLA, the introduction of PLA in solution resulted in an initial drop of pH to 2.65 (Fig. 2a, with $\mathrm{p} K_{\mathrm{a}}$ of lactic acid $=3.86$ at $20^{\circ} \mathrm{C}$ ) and a first increase of conductivity to $350 \mu \mathrm{S} \mathrm{cm}^{-1}$ (Fig. 2d). Initially, the ORP values were fixed by the $\mathrm{Fe}(\mathrm{III}) / \mathrm{Fe}$ (II) redox couple (Figs. $2 \mathrm{~b}$ and c) that result from the initial partial breaking of the iron oxide shell under acidic conditions (Sarathy et al. 2008; Tang et al. 2017a). This agrees with the initial decrease and stabilization of $\mathrm{pH}$ as $\mathrm{Fe}^{3+}$ acts as a weak Brønsted acid (Shih et al. 2011), as indicated in Eq. 5.

$$
\mathrm{Fe}^{3+}+\mathrm{H}_{2} \mathrm{O} \rightarrow \mathrm{Fe}(\mathrm{OH})^{2+}+\mathrm{H}^{+}
$$

After 420 minutes, the $\mathrm{pH}$ increased from 2.65 to 6.15 , and the rate of $\mathrm{H}^{+}$consumption is not linear but decreases with time, as shown by the cumulative $\mathrm{H}^{+}$consumption (Fig. S3). After an initial decrease, the conductivity stabilized at a minimum value of $195 \mu \mathrm{S} \mathrm{cm} \mathrm{cm}^{-1}$ after $100 \mathrm{~min}$. The decrease in $\mathrm{H}^{+}$content was therefore compensated by an increase in other ionic-species contents, especially soluble $\mathrm{Fe}^{2+}$ and $\mathrm{Fe}^{3+}$. After that, conductivity slowly increased to $230 \mu \mathrm{S} \mathrm{cm}^{-1}$ at $420 \mathrm{~min}$.

According to the Nernst equation of the $\mathrm{Fe}(\mathrm{III}) / \mathrm{Fe}(\mathrm{II})$ redox couple, an increase in $\mathrm{Fe}^{2+}$ content resulting from iron corrosion (Eq. 1) causes a decrease in ORP values in the first minutes. Then, ORP drops from positive to negative values (Fig. 2b), which indicates a change in the main redox couple in the system. As shown on Fig. 2c, this change is well correlated with the theoretical evolution of the $\mathrm{H}^{+} / \mathrm{H}_{2}$ redox couple with pH. Hence, the monitoring of ORP is a good indicator for the formation and accumulation of $\mathrm{H}_{2}$ in the system. A similar behaviour was observed for the aqueous corrosion of nZVI particles in PLA (Fig. S4), confirming that the 
changes in solution chemistry are well related to the particles. However, all phenomena accelerated when using nZVI particles. The $\mathrm{pH}$ increased from 2.75 to 6.15 in less than $60 \mathrm{~min}$, resulting in a more rapid initial decrease in both ORP and conductivity. This acceleration is probably related to the difference in specific surface area $\left(a_{\mathrm{S}}\right.$ ${ }_{\mathrm{nZVI}} \mathrm{BET}=15.5 \mathrm{~m}^{2} \mathrm{~g}^{-1}$ ) and in the cathode/anode ratio. The nZVI particles thus show a much faster corrosion rate than Pd-mZVI particles, the latter having a longer reactive lifetime.

The increase in PLA content from 850 to $3400 \mathrm{mg}$ led to a decrease in initial pH (Fig. 2a) due to PLA hydrolysis, resulting in an increase in initial conductivity (Fig. 2d). Similar changes of pH and ORP were observed, but with a time delay; the decrease and stabilization of $\mathrm{pH}$ values (Fig. 2a) and the fixing of ORP by the $\mathrm{Fe}(\mathrm{III}) / \mathrm{Fe}(\mathrm{II})$ redox couple (Figs. 2b, c) were observed during $40 \mathrm{~min}$. After that, the $\mathrm{pH}$ sharply increased reflecting a more rapid decrease in conductivity (Fig. 2d), and the change of ORP from the $\mathrm{Fe}(\mathrm{III}) / \mathrm{Fe}(\mathrm{II})$ to the $\mathrm{H}^{+} / \mathrm{H}_{2}$ redox couple occurred shortly after. Compared with the experiment conducted with $850 \mathrm{mg}$ of PLA, this evolution of the solution chemistry thus suggests that, despite an initial decrease in $\mathrm{pH}$, iron corrosion is slow from 0 to $40 \mathrm{~min}$, becoming important only after that. The polymeric coating can alter the reactivity of ironbased particles due to (i) the blocking of reactive sites and (ii) the inhibition of mass transfer to the surface due to the formation of trains and loops (Phenrat et al. 2009). Increasing the PLA content results in blocking of the reactive cathodic sites and the creation of an extensive polymer layer on the surface. Iron corrosion thus appears to be initially cathodically controlled by $\mathrm{H}^{+}$mass transport to the Pd surface, the effect being more pronounced when the PLA content is increased. Increasing the $\mathrm{H}^{+}$content at the interface causes an increase in corrosion rate, resulting in the saturation of $\mathrm{Pd}$ and the later recombination of $\mathrm{H}^{*}$ into $\mathrm{H}_{2}$. A schematic illustration of the main results obtained in this section is proposed on Fig. 3.

Continuous $\mathrm{pH}, \mathrm{ORP}$ and conductivity measurements allowed monitoring the consumption of $\mathrm{H}^{+}$, mainly related to iron corrosion, and the production/accumulation of $\mathrm{H}_{2}$ in the system according to the E-pH diagram.

\subsection{Investigation of the $\mathrm{Pd}-\mathrm{mZVI} / \mathrm{PLA} / \mathrm{HCA} / \mathrm{H}_{2} \mathrm{O}$ system}

\subsubsection{Effects of Pd-mZVI dosage}

The effect of Pd-mZVI dosage was investigated with 150,375 and $600 \mathrm{mg}$ at $25{ }^{\circ} \mathrm{C}$ with $850 \mathrm{mg}$ of PLA and $10 \mathrm{mg} \mathrm{L}^{-1}$ of $\mathrm{HCA}$ (Fig. 4). It is important to note that the theoretical stoichiometric requirement is $1.42 \mathrm{~g} \mathrm{Fe}^{0} / \mathrm{g}$ of HCA for its complete reduction to ethane. HCA completely disappears in less than 120 min with $600 \mathrm{mg}$ of Pd-mZVI, while the degradation remains incomplete after 420 min with 150 and $375 \mathrm{mg}$ (Fig. 4a). An increase in Pd-mZVI dosage results in more active sites for $\mathrm{H}^{+}$reduction and $\mathrm{H}^{*}$ generation (cathodic sites), as confirmed 
by the more rapid increase in $\mathrm{pH}$ (Fig. 4b). As shown on Figs. $4 \mathrm{~d}$ and e, ORP remained fixed by the $\mathrm{Fe}(\mathrm{III}) / \mathrm{Fe}$ (II) redox couple with 150 and $375 \mathrm{mg}$, while the change from $\mathrm{Fe}(\mathrm{III}) / \mathrm{Fe}(\mathrm{II})$ to $\mathrm{H}^{+} / \mathrm{H}_{2}$ was observed with $600 \mathrm{mg}$. This result agrees with the more rapid and greater production of $\mathrm{H}_{2}$. With 150 and $375 \mathrm{mg}$ of PdmZVI, the conductivity decreases during the $420 \mathrm{~min}$ of reaction time (Fig. 4f). This decrease is observed during the first 90 min with $600 \mathrm{mg}$ of Pd-mZVI. As $\mathrm{H}^{+}$is the major contributor to conductivity under strong acidic conditions, this variation can be explained by a decrease in $\mathrm{H}^{+}$content due to iron corrosion.

HCA reduction results in the formation and accumulation of PCE $\left(\mathrm{C}_{2} \mathrm{Cl}_{4}\right)$ as the only chlorinated intermediate (Fig. 4c), in agreement with the dihalo-elimination pathway observed in earlier studies with ZVI-based particles (Lien and Zhang 2005; Song and Carraway 2005; Wu et al. 2014). However, our results showed that the initial disappearance of HCA was not directly related to PCE production, as a 10-min shift was observed for PCE production irrespective of the amount of particles. This delay may indicate that HCA degradation initially involves nonreductive sorption on the Pd-mZVI/PLA $/ \mathrm{H}_{2} \mathrm{O}$ system, which is generally linked to the carbon content on the particle surfaces (Lin and Lo 2005; Velimirovic et al. 2013b). In addition, this induction period could be caused by the absence of active hydrogen species $\left(\mathrm{H}^{*}{ }_{\text {ads }}\right)$ on the Pd surface, as He et al. (2018) suggested that the dechlorination process on $\mathrm{Pd}$ particles requires first their saturation by $\mathrm{H}^{*}$ (formation of palladium hydride) before any dechlorination reaction.

With $600 \mathrm{mg}$ of Pd-mZVI, the change from positive to negative ORP values occurs after $100 \mathrm{~min}$ (Fig. 4d) whereas it occurs after only $35 \mathrm{~min}$ in the absence of HCA (Fig. $2 \mathrm{~b}$ ), showing that $\mathrm{H}^{*}$ is consumed during dechlorination. This change is observed only when the PCE concentration becomes low, indicating that $\mathrm{H}^{*}$ is the main reductant for both HCA and PCE degradation. However, the degradation mechanism seems different for both compounds. HCA reduction to PCE (Eq. 6) does not involve the addition of hydrogen in the molecule; atomic hydrogen acts therefore only as an electron donor. Even if this result seems to disagree with the increase in $\mathrm{pH}$, it is important to note that iron particles have a very low electron efficiency toward contaminants, i.e. most parts of iron react with water (Schöftner et al. 2015; Fan et al. 2016; Tang et al. 2017b). PCE reduction results in the formation of ethane, ethylene and $\mathrm{C}_{4}$ compounds (Fig. S6), without accumulation of chlorinated intermediates in solution. This result was confirmed by GC/MS measurements with lower quantitation limits (0.1-1 $\mu \mathrm{g} \mathrm{L} \mathrm{L}^{-1}$ depending on the compound). The production of $\mathrm{C}_{4}$ compounds indicates that coupling reactions occur during the reaction. Hence, PCE reduction first results in the formation of $\mathrm{C}_{2}$ surface complexes, with the 

2008), followed by progressive hydrogenation and/or coupling reactions between $C_{2}$ fragments (Eqs. 7-10).

$$
\begin{gathered}
\mathrm{CCl}_{3} \mathrm{CCl}_{3}+2 \mathrm{e}^{-} \rightarrow \mathrm{CCl}_{2}=\mathrm{CCl}_{2}+2 \mathrm{Cl}^{-} \\
\mathrm{CCl}_{2}=\mathrm{CCl}_{2} \stackrel{\mathrm{Pd}}{\rightarrow} \mathrm{C}_{2}^{\ddagger}+4 \mathrm{Cl}^{-} \\
\mathrm{C}_{2}^{\ddagger}+6 \mathrm{H}^{*} \stackrel{\mathrm{Pd}}{\rightarrow} \mathrm{C}_{2} \mathrm{H}_{6} \\
\mathrm{C}_{2}^{\ddagger}+4 \mathrm{H}^{*} \stackrel{\text { Pd }}{\rightarrow} \mathrm{C}_{2} \mathrm{H}_{4} \\
\mathrm{C}_{2}^{\ddagger}+\mathrm{C}_{2}^{\ddagger} \stackrel{\text { Pd }}{\rightarrow} \mathrm{C}_{4}^{\ddagger}
\end{gathered}
$$

292

With $600 \mathrm{mg}$ of Pd-mZVI, the small increase in ORP values (Fig. 4d)—causing a gap in the $\mathrm{H}^{+} / \mathrm{H}_{2}$ redox couple theoretical values observed after $120 \mathrm{~min}$ (Fig. 4e) - is caused by the loss of $\mathrm{H}_{2}$ during sampling, as ORP remains well fixed by the $\mathrm{H}^{+} / \mathrm{H}_{2}$ redox couple without opening of the reactor (Fig. 2c). The effect is more pronounced for the penultimate sampling at 330 min because of the decrease in $\mathrm{H}^{+}$content and the rate of iron corrosion. The effect is even more pronounced with nZVI particles (Fig. S4), where a decrease in $\mathrm{pH}$ is observed after $80 \mathrm{~min}$ associated with a progressive increase in ORP every time the reactor is opened. These results indicate a consumption of $\mathrm{OH}^{-}$and the formation of iron oxy-hydroxides on the surface of nZVI particles such as lepidocrocite $\gamma$-FeOOH, because of the possible introduction of dissolved $\mathrm{O}_{2}$ (Greenlee et al. 2012; Liu et al. 2014a), as well as of ferrihydrite because of the presence of lactate ions (Sabot et al. 2007).

Zero-order, pseudo-first-order and second-order reactions were envisaged for fitting the experimental data. With 150 and $375 \mathrm{mg}$ of Pd-mZVI, none of them resulted in a correct representation of HCA degradation (see Table 1 for the results of pseudo-first-order equations). In these cases, a two-compartment model based on first-order equations (Eq. 11) fits well with the experimental data obtained (Fig. S6), suggesting that two different reaction mechanisms explain the disappearance of HCA (Rodrigues et al. 2017a; Kim et al. 2018).

$$
\frac{C}{C_{0}}=\alpha \mathrm{e}^{-k_{\mathrm{a}} t}+(1-\alpha) \mathrm{e}^{-k_{\mathrm{c}} t}
$$

where $C_{0}$ is the initial pollutant concentration, $C$ is the pollutant concentration at time $t(\min ), k_{\mathrm{a}}$ and $k_{\mathrm{c}}$ are respectively the rate constants for adsorption and chemical degradation, $\alpha$ represents the weight value for sorption, and 1- $\alpha$ represents the weight value for chemical degradation.

With $600 \mathrm{mg}$ of Pd-mZVI, the production of atomic hydrogen $\mathrm{H}^{*}$ on the Pd surface is more important due to increased $\mathrm{H}^{+}$consumption. The rate-determining step then moves progressively from $\mathrm{H}^{*}$ production to hydro- 

(Eq. 12):

$$
\frac{C}{C_{0}}=e^{-k_{\mathrm{obs}} t}
$$
where $C$ is the concentration $\left(\mathrm{mg} \mathrm{L}^{-1}\right)$ at time $t(\mathrm{~min}), C_{0}$ is the initial concentration $\left(\mathrm{mg} \mathrm{L}^{-1}\right)$ and $k_{\mathrm{obs}}$ is the rate constant $\left(\min ^{-1}\right)$.

In the following section, we focus on the use of $600 \mathrm{mg}$ of Pd-mZVI in order to observe as much variation as possible in the different experimental parameters for a better understanding of the HCA degradation mechanism.

\subsubsection{Effects of temperature}

The effect of temperature was investigated at 12,25 and $35{ }^{\circ} \mathrm{C}$ with $600 \mathrm{mg}$ of Pd-mZVI, $850 \mathrm{mg}$ of PLA and $10 \mathrm{mg} \mathrm{L}^{-1}$ of HCA (Fig. 5). As already observed in our previous study (Rodrigues et al. 2017a), the increase in temperature results in a decrease in the initial $\mathrm{pH}$ due to a change in the rate of PLA hydrolysis. Results show that HCA degradation is incomplete at $12{ }^{\circ} \mathrm{C}$ after $420 \mathrm{~min}$ (Fig. 5a). During this period, the $\mathrm{pH}$ increases from 2.94 to 3.48 (Fig. 5b), and only a decrease in conductivity with time from 390 to $225 \mu \mathrm{S} \mathrm{cm} \mathrm{cm}^{-1}$ is observed (Fig. 5f), indicating that iron corrosion is slow. At $35^{\circ} \mathrm{C}$, the HCA has completely disappeared after about 60 min, more rapidly than at $25^{\circ} \mathrm{C}$ (Fig. 5a), and PCE accumulates at a lower rate and disappears more rapidly at evolution of conductivity is more difficult here as the molar conductivity of each species is different at each temperature, but the results confirm that iron corrosion is more rapid when the temperature increases (Fig. 5f). The constant increase in HCA degradation rate with temperature (Table 1) can then be explained by the more rapid production of atomic hydrogen on the Pd surface (He and Zhao 2008).

This agrees with the evolution in ORP values over time. At $12{ }^{\circ} \mathrm{C}$, ORP is stable for $100 \mathrm{~min}$ and only a small decrease is observed afterwards (Fig. 5d), indicating an increase in $\mathrm{Fe}^{2+}$ content in the solution. The ORP does not decrease to the $\mathrm{H}^{+} / \mathrm{H}_{2}$ redox couple values because of the slow production of atomic hydrogen and its subsequent reaction with HCA. Conversely, the accumulation of $\mathrm{H}_{2}$, according to ORP measurements (Fig. 5d), decrease in $\mathrm{H}^{+}$consumption under less acidic conditions $(\mathrm{pH}>5)$ is observed earlier at $35^{\circ} \mathrm{C}$. After the last opening of the reactor at $330 \mathrm{~min}$, the ORP becomes positive, indicating that the $\mathrm{H}^{+} / \mathrm{H}_{2}$ redox couple is no longer 
the main contributor to the overall ORP value (Figs. 5d and e). Also, the small decrease in pH observed could indicate an $\mathrm{OH}^{-}$consumption related to the formation of iron oxy-hydroxides on the particle surfaces. Thus, even if the temperature increase is favourable for HCA degradation, the reactive lifetime of the particles and the electron efficiency are strongly impacted. We thus focused on the use of $T=25^{\circ} \mathrm{C}$ for the subsequent experiments.

Considering the pseudo-first-order model, the Arrhenius equation was used for establishing the relation between the rate constant and the temperature (Eq. 13).

$$
\ln k_{\mathrm{obs}}=\ln A-\frac{E_{a}}{R T}
$$

where $k_{\mathrm{obs}}$ is the constant rate $\left(\mathrm{min}^{-1}\right), A$ is the pre-exponential factor $\left(\mathrm{min}^{-1}\right), E_{\mathrm{a}}$ is the activation energy $\left(\mathrm{J} \mathrm{mol}^{-1}\right)$, $R$ is the universal gas constant and $T$ is the absolute temperature $(\mathrm{K})$. An almost equivalent relationship, the Eyring equation, can be used by following the transition state theory (Eq. 14).

$$
k_{\mathrm{obs}}=\frac{k_{\mathrm{B}} T}{h} \exp \left(\frac{-\Delta^{\ddagger} G^{\circ}}{R T}\right)
$$

where $k_{\mathrm{B}}$ is the Boltzmann constant $\left(1.38110^{-23} \mathrm{~J} \mathrm{~K}^{-1}\right), h$ is the Planck constant $\left(6.62610^{-34} \mathrm{~J} \mathrm{~s}\right)$ and $\Delta^{\ddagger} G^{\circ}$ is the Gibbs energy of activation $\left(\mathrm{J} \mathrm{mol}^{-1}\right)$. The relation can be linearized as Eq. 15:

$$
\ln \left(\frac{k_{\mathrm{obs}}}{T}\right)=\frac{-\Delta^{\ddagger} H^{\circ}}{R} \cdot \frac{1}{T}+\ln \left(\frac{k_{\mathrm{B}}}{h}\right)+\frac{\Delta^{\ddagger} S^{\circ}}{R}
$$

where $\Delta^{\ddagger} H^{\circ}$ is the standard enthalpy of activation $\left(\mathrm{J} \mathrm{mol}^{-1}\right)$ and $\Delta^{\ddagger} S^{\circ}$ is the standard entropy of activation $\left(\mathrm{J}\right.$ mol ${ }^{-}$ $\left.{ }^{1} \cdot \mathrm{K}^{-1}\right)$.

Results obtained from the Arrhenius plot are $E a=106.5 \mathrm{~kJ} \mathrm{~mol}^{-1}$ and $A=1.2110^{17} \mathrm{~min}^{-1}\left(R^{2}=0.982\right.$, Fig. S8a). The elevated activation energy indicates that, with these experimental parameters, the overall reaction is controlled by the reaction on the particle surfaces (Pilling and Seakins 1995). Results obtained from the Eyring plot are $\Delta^{\ddagger} H^{\circ}=104.0 \mathrm{~kJ} \mathrm{~mol}^{-1}$ and $\Delta^{\ddagger} S^{\circ}=39.8 \mathrm{~J} \mathrm{~mol}^{-1} \mathrm{~K}^{-1}\left(R^{2}=0.981\right.$, Fig. S8b $)$. The positive value for the activation entropy indicates that the reaction is favourable and that the activated complex is loosely bound on the surface of the particles, which agrees with the formation and desorption of PCE as a reaction intermediate. Based on previous studies (Butler and Hayes 1998; Patterson et al. 2001; Song and Carraway 2005; Huang et al. 2012; Pizarro et al. 2018), the activated complex is suspected to be the pentachloroethyl radical (Eqs. 16-17). 


$$
\begin{aligned}
& \mathrm{C}_{2} \mathrm{Cl}_{6}+\mathrm{e}^{-} \rightarrow{ }^{\cdot} \mathrm{C}_{2} \mathrm{Cl}_{5}+\mathrm{Cl}^{-} \\
& { }^{\circ} \mathrm{C}_{2} \mathrm{Cl}_{5}+\mathrm{e}^{-} \rightarrow \mathrm{C}_{2} \mathrm{Cl}_{4}+\mathrm{Cl}^{-}
\end{aligned}
$$

\subsubsection{Effects of HCA initial concentration}

The effect of the initial concentration was investigated at three HCA initial concentrations—5, 10 and $20 \mathrm{mg} \mathrm{L}^{-}$ ${ }^{1}$-at $25^{\circ} \mathrm{C}$ with $600 \mathrm{mg}$ of Pd-mZVI and $850 \mathrm{mg}$ of PLA (Fig. 6). A change in initial concentration of the substrate has no influence on the degradation pathways, with the production of PCE and its subsequent reduction to ethane, ethylene and $\mathrm{C}_{4}$ compounds (Fig. S9). HCA degradation-rate constants are very similar when the initial concentration increases from $5 \mathrm{mg} \mathrm{L}^{-1}\left(k_{\mathrm{obs}}=0.036 \mathrm{~min}^{-1}\right)$ to $10 \mathrm{mg} \mathrm{L}^{-1}\left(k_{\mathrm{obs}}=0.035 \mathrm{~min}^{-1}\right.$, see Table 1$)$. As the evolution of $\mathrm{H}^{+}$content is quite different at both concentrations (Figs. $6 \mathrm{~b}$ and $\mathrm{S} 2$ ), the rate-determining step cannot be attributed to $\mathrm{H}^{*}$ production, but rather to HCA dechlorination.

An increase in HCA content to $20 \mathrm{mg} \mathrm{L}^{-1}$ results in a decrease in the degradation rate constant $\left(k_{\mathrm{obs}}=0.010 \mathrm{~min}^{-}\right.$ ${ }^{1}$ ), and PCE accumulates over a longer time, but in a similar proportion as obtained with lower initial concentrations (Fig. 6c). As indicated by the $\mathrm{pH}$ evolution (Fig. 6b) and cumulative $\mathrm{H}^{+}$consumption (Fig. S3), the production of $\mathrm{H}^{*}$ is less rapid with $20 \mathrm{mg} \mathrm{L}^{-1}$, whereas the degradation requires twice as much atomic hydrogen. As observed in Figs. 6d and e, the ORP value remains positive and is not fixed by the $\mathrm{H}^{+} / \mathrm{H}_{2}$ redox couple during the 420 min of the experiment. As shown on Fig. S10, the drop in ORP values is observed only after the complete hydrodechlorination of PCE. So, as long as dechlorination occurs, the most important fraction of $\mathrm{H}^{*}$ ads available on $\mathrm{Pd}$ is consumed, which prevents its recombination into $\mathrm{H}_{2}$ and its subsequent desorption. Therefore, even if the degradation rate constant is lower, a low iron/pollutant ratio will limit the loss of active hydrogen species. This result is comparable to that obtained by decreasing the amount of Pd-mZVI, where a similar evolution of conductivity with time is observed (Fig. 6f). Hence, for higher HCA initial concentrations (>20 mg L $\mathrm{m}^{-1}$ ) with $600 \mathrm{mg}$ of Pd-mZVI, the reaction may be limited by the production of $\mathrm{H}^{*}$ and not by surfacereaction kinetics.

In the following section, we thus focus on the use of $10 \mathrm{mg} \mathrm{L}^{-1}$ as the initial HCA concentration.

\subsubsection{Effects of PLA content}

The effect of the PLA content was investigated for three initial contents $-850,1700$ and $3400 \mathrm{mg}-$ at $25^{\circ} \mathrm{C}$ with $600 \mathrm{mg}$ Pd-mZVI and $10 \mathrm{mg} \mathrm{L}^{-1} \mathrm{HCA}$ (Fig. 7). The increase in PLA content results in a decrease in HCA degradation rate constants, from $0.035 \mathrm{~min}^{-1}$ with $850 \mathrm{mg}$ to $0.025 \mathrm{~min}^{-1}$ at $3400 \mathrm{mg}$ (Table 1), in agreement with 
the later production and accumulation of PCE (Fig. 7c). With $3400 \mathrm{mg}$, more than $40 \%$ of HCA disappears in the first $10 \mathrm{~min}$, which indicates a more important phase transfer from water to PLA (sorption). As no PCE production is observed during this time, HCA accumulates near the surface of the particles. Compared to the experiment run in the Pd-mZVI/PLA/ $\mathrm{H}_{2} \mathrm{O}$ system (Fig. 2), the evolution of $\mathrm{pH}$, ORP and conductivity follows the same qualitative trend (Figs. $7 \mathrm{~b}, \mathrm{~d}$ and f), although $\mathrm{H}^{+}$consumption is less important in the first minutes (Fig. S3) and the change from a $\mathrm{Fe}(\mathrm{III}) / \mathrm{Fe}(\mathrm{II})$ to a $\mathrm{H}^{+} / \mathrm{H}_{2}$ redox couple occurs much later.

In the Pd-mZVI/PLA/ $\mathrm{H}_{2} \mathrm{O}$ system, the reductive dechlorination process requires an intimate contact between pollutant and particle surface. However, as mentioned before, the increase in polymeric coating can result in a high coverage rate of the particles (site blocking) and the development of an extended layer composed of loops and tails (Zhu et al. 2008; Phenrat et al. 2009; Bhattacharjee et al. 2016; Louie et al. 2016). With $1700 \mathrm{mg}$ of PLA, the lower HCA rate constant can be attributed to higher number of sites blocked by the polymeric coating and to a low production of atomic hydrogen in the first minutes. After the initial decrease and stabilization of $\mathrm{pH}$ (Fig. 7b), the strong acidic conditions accelerate the rate of $\mathrm{H}^{+}$consumption (Fig. S3), which results in a more rapid production of $\mathrm{H}^{*}$. As a consequence, PCE degradation occurs rapidly. With $3400 \mathrm{mg}$ of PLA, the development of loops and tails on the particle surfaces will impede HCA mass transport to the surface of the particles, the accumulation of $\mathrm{HCA}$ in turn impeding $\mathrm{H}^{+}$mass transport, which explains the decrease in degradation rate. In addition, the accumulation of $\mathrm{H}_{2}$ bubbles around the particles can result in the covering of reactive sites and the deactivation of the catalyst (Graham and Jovanovic 1999; Wang et al. 2009), leading to a further decrease in the degradation rate (Huang et al. 2016).

Even if the degradation rates decrease with increasing PLA content, the reactive lifetime of the particles is extended thanks to the formation of iron lactate complexes and the maintenance of acidic conditions, which prevent the rapid formation of any passive layer on the surface of the particles (Rodrigues et al. 2017a) as $\mathrm{Fe}^{3+}$ and $\mathrm{Fe}^{2+}$ are more soluble under acidic conditions, and thus the rapid enclosure of Pd (Yan et al. 2010; Ling and Zhang 2014).

As shown in the previous experiments, for a given initial HCA concentration, an increase in Pd-mZVI dosage causes an increase in the HCA degradation rate, but a major part of the $\mathrm{H}^{*}$ will be combined as $\mathrm{H}_{2}$, rendering it unavailable for degradation. Therefore, it appears necessary to seek a compromise between HCA degradation rate and electron efficiency. A 15:85 mass ratio of Pd-mZVI in PLA appears to be an optimal condition that 
allows a rapid initial disappearance of the pollutant, a more controlled reactivity and the maintenance of acidic conditions, extending the reactive lifetime of the particles and preventing the formation of passive precipitates.

\subsection{HCA dechlorination mechanism}

Figure 8 shows a summary of the main conclusions of the dechlorination mechanism. The introduction in water of a suspension of Pd-mZVI in PLA results in the partial breaking up of the initial shell (Sarathy et al. 2008; Tang et al. 2017a); $\mathrm{Fe}^{0}$ oxidizes to $\mathrm{Fe}^{2+}$, and the resulting electrons flow from the iron core to Pd that acts as the main cathodic site $\left(E_{\mathrm{Pd}}^{0}>E_{\mathrm{FeOx}}^{0}>E_{\mathrm{Fe}}^{0}\right)$. On the Pd surface, which is a good catalyst for hydrogenation, $\mathrm{H}^{+}$is reduced to atomic hydrogen $\mathrm{H}^{*}$ (Volmer step), accumulating as palladium hydride (Pd-H) and as $\mathrm{H}_{\text {ads }}^{*}$. Finally, the reaction of $\mathrm{H}^{+}$with $\mathrm{H}^{*}$ ads (Heyrovsky step), or the combination of two $\mathrm{H}_{\text {ads }}^{*}$ (Tafel step), will result in the desorption of $\mathrm{H}_{2}$ to the bulk solution (Fig. 3).

In the presence of HCA, the first step is mass transfer of HCA from bulk to suspension of the Pd-mZVI/PLA system. As both HCA and PLA are hydrophobic, the initial HCA disappearance is attributed to nonreductive sorption, in agreement with the absence of PCE production and the increase in initial disappearance when increasing the PLA content. The second step is the surface reaction of HCA with $\mathrm{H}^{*}$, which results in the production and accumulation of PCE as a chlorinated by-product. The absence of other chlorinated intermediates and the production of $\mathrm{C}_{4}$ compounds suggest that PCE undergoes rapid dechlorination, because of the breaking of C-Cl bonds on the Pd surface (Sriwatanapongse et al. 2006; Heck et al. 2008) and the formation of $\mathrm{C}_{2}^{\ddagger}$ surface complexes. The third step is the progressive hydrogenation of $C_{2}^{\ddagger}$ into $C_{2}$ compounds, or a coupling reaction between two surface complexes into $\mathrm{C}_{4}^{\ddagger}$ and its progressive hydrogenation to $\mathrm{C}_{4}$ compounds. The last steps are the desorption of the products from the surface of the particles, and their transfer to the bulk solution (Fig. 8).

\subsection{Implications for environmental application}

In addition to proposing a degradation mechanism, our study allows defining some perspectives for practical applications. The laboratory results suggest that small $\left(\approx 600 \mathrm{mg}\right.$ for $\left.[\mathrm{HCA}]_{0}=5-20 \mathrm{mg} \mathrm{L}^{-1}\right)$ amounts of PdmZVI in PLA are sufficient for a rapid and complete pollution degradation. The use of low doses of iron particles will limit the loss of ZVI due to its spontaneous corrosion in water, as well as reducing its inhibition effects on the microbial community for in situ remediation (Velimirovic et al. 2015). Even if an increase in PLA content results in more acidic conditions, the effect may be less pronounced under field conditions depending on the natural buffering capacity of the aquifer. In addition, as indicated above, iron corrosion progressively results in an increase of $\mathrm{pH}$ to near-neutral conditions, more favourable to the growth and activity of organohalide- 
respiring bacteria, e.g. Dehalococcoides strains, for biological reductive dechlorination, even if a $\mathrm{pH}$ decrease will affect the ability of the culture to dechlorinate (Yang et al. 2017a, b). The monitoring of pH thus is a great tool for evaluating the operating conditions for both abiotic and biotic reductive processes.

Interpretation of the ORP evolution should be more difficult in the field than in laboratory experiments, because of the many redox couples and bacteria in groundwater that contribute to the overall (mixed potential) ORP value (Hunting and Kampfraath 2013; Shi et al. 2015). Measuring ORP will nevertheless provide insight into the creation of reductive conditions due to $\mathrm{H}_{2}$ production. In addition, the impact on ORP values of opening the reactor could mirror the influence of sampling from observation wells in the field, as ORP values are known to have a harmful effect on iron reactivity, and on the presence and activity of organohalide-respiring bacteria (Adrian and Löffler 2016). Finally, conductivity measurements should give indications on the ionic strength of groundwater. The overall data acquired during this study have shown the interest of implementing a complete multi-parametric device for the monitoring of reductive dechlorination processes in the field.

\section{Conclusion}

We investigated the mechanism of HCA degradation by a suspension of Pd-mZVI particles in PLA, using indirect continuous monitoring of iron corrosion by means of measuring $\mathrm{pH}$, ORP and conductivity. HCA dechlorination involves the formation and accumulation of PCE as an intermediate compound, before its subsequent reduction to non-chlorinated $\mathrm{C}_{2}$ and $\mathrm{C}_{4}$ compounds. The increase in Pd-mZVI dosage results in an increased HCA degradation rate due to a greater production of atomic hydrogen $\mathrm{H}^{*}$. With $600 \mathrm{mg}$ of Pd-mZVI particles, a temperature increase is favourable to HCA degradation as the production of $\mathrm{H}^{*}$ is accelerated, but at the expense of the reactive lifetime of the particles. Increasing the initial HCA concentration to $20 \mathrm{mg} \mathrm{L}^{-1}$ leads to a decrease in the degradation rate constant. Finally, an increase in PLA content decreases the global degradation rate due to an enhanced contact between HCA and the particle surfaces that decreases the production of $\mathrm{H}^{*}$, but the maintaining of acidic conditions can prevent the rapid formation of any passive precipitates. Our results indicate that the HCA degradation mechanism includes mass transfer, nonreductive sorption, surface reaction with $\mathrm{H}^{*}$ and desorption of the product. Combined with gas chromatography, the continuous monitoring of physical and chemical parameters of the bulk solution was proven to be a powerful tool in laboratory experiments for the indirect investigation of dechlorination mechanisms in the Pd-mZVI/PLA/ $\mathrm{H}_{2} \mathrm{O}$ system. 
471 Supplementary data are associated with this article.

\section{Declaration of interest}

473 None

\section{Acknowledgements}

475 This work was supported by the French Environment and Energy Management Agency (ADEME) and the 476 French Geological Survey (BRGM) within the framework of the AMI SILPHES project coordinated by David 477 Cazaux (Inovyn Tavaux). The authors acknowledge Benoit Castermans (Biorem Engineering) for providing PdmZVI particles and PLA, Nicolas Maubec (BRGM) for performing XRD analyses, and Christian Perruchot and Philippe Decorse (ITODYS laboratory, Université Paris Diderot) for performing XPS analyses. Romain Rodrigues thanks Chérif Morcos for fruitful discussions. The authors thank the anonymous reviewers for their helpful comments and suggestions. H.M. Kluijver edited the English language of the final MS.

\section{References}

Adrian L, Löffler FE (2016) Organohalide-Respiring Bacteria. Springer, Berlin, Heidelberg

Aulenta F, Fuoco M, Canosa A, Papini MP, Majone M (2008) Use of poly- $\beta$-hydroxy-butyrate as a slow-release electron donor for the microbial reductive dechlorination of TCE. Water Sci Technol 57:921. doi: $10.2166 /$ wst. 2008.073

Bae S, Collins RN, Waite TD, Hanna K (2018) Advances in surface passivation of nanoscale zerovalent iron (NZVI): A critical review. Environ Sci Technol acs.est.8b01734. doi: 10.1021/acs.est.8b01734

Bae S, Hanna K (2015) Reactivity of nanoscale zero-valent iron in unbuffered systems: Effect of pH and Fe(II) dissolution. Environ Sci Technol 49:10536-10543. doi: 10.1021/acs.est.5b01298

Baer DR, Amonette JE, Engelhard MH, Gaspar DJ, Karakoti AS, Kuchibhatla S, Nachimuthu P, Nurmi JT, Qiang Y, Sarathy V, Seal S, Sharma A, Tratnyek PG, Wang C-M (2008) Characterization challenges for nanomaterials. Surf Interface Anal 40:529-537. doi: 10.1002/sia.2726 (ZVI) for enhanced treatment of chlorinated ethanes in permeable reactive barriers (PRBs). Chem Eng J 
Bhattacharjee S, Basnet M, Tufenkji N, Ghoshal S (2016) Effects of rhamnolipid and carboxymethylcellulose coatings on reactivity of palladium-doped nanoscale zerovalent iron particles. Environ Sci Technol 50:1812-1820. doi: 10.1021/acs.est.5b05074

Bruton TA, Pycke BFG, Halden RU (2015) Effect of nanoscale zero-valent iron treatment on biological reductive dechlorination: A review of current understanding and research needs. Crit Rev Environ Sci Technol 45:1148-1175. doi: 10.1080/10643389.2014.924185

Butler EC, Hayes KF (1998) Effects of solution composition and $\mathrm{pH}$ on the reductive dechlorination of hexachloroethane by iron sulfide. Environ Sci Technol 32:1276-1284. doi: 10.1021/es9706864

Chaplin BP, Reinhard M, Schneider WF, Schüth C, Shapley JR, Strathmann TJ, Werth CJ (2012) Critical review of Pd-based catalytic treatment of priority contaminants in water. Environ Sci Technol 46:3655-3670. doi: $10.1021 / \mathrm{es} 204087 \mathrm{q}$

Chronopoulou L, Palocci C, Valentino F, Pettiti I, Wacławek S, Černík M, Papini MP (2016) Stabilization of iron (micro)particles with polyhydroxybutyrate for in situ remediation applications. Appl Sci 6:417. doi: 10.3390/app6120417

Comba S, Di Molfetta A, Sethi R (2011) A comparison between field applications of nano-, micro-, and millimetric zero-valent iron for the remediation of contaminated aquifers. Water, Air, Soil Pollut 215:595607. doi: 10.1007/s11270-010-0502-1

Crane RA, Scott TB (2012) Nanoscale Zero-Valent Iron: Future Prospects for an Emerging Water Treatment Technology. J Hazard Mater 211:112-125. doi: 10.1016/j.jhazmat.2011.11.073

De Windt W, Aelterman P, Verstraete W (2005) Bioreductive deposition of palladium (0) nanoparticles on Shewanella oneidensis with catalytic activity towards reductive dechlorination of polychlorinated biphenyls. Environ Microbiol 7:314-325. doi: 10.1111/j.1462-2920.2005.00696.x

Dien NT, De Windt W, Buekens A, Chang MB (2013) Application of bimetallic iron (BioCAT slurry) for pentachlorophenol removal from sandy soil. J Hazard Mater 252:83-90. doi: 10.1016/j.jhazmat.2013.02.029 
Elliott DW, Zhang W (2001) Field assessment of nanoscale bimetallic particles for groundwater treatment. Environ Sci Technol 35:4922-4926. doi: 10.1021/es0108584

Fan D, O’Carroll DM, Elliott DW, Xiong Z, Tratnyek PG, Johnson RL, Garcia AN (2016) Selectivity of nano zerovalent iron in in situ chemical reduction: Challenges and improvements. Remediat J 26:27-40. doi: $10.1002 / \mathrm{rem} .21481$

Fang L, Xu C, Zhang W, Huang L-Z (2018) The important role of polyvinylpyrrolidone and Cu on enhancing dechlorination of 2,4-dichlorophenol by $\mathrm{Cu} / \mathrm{Fe}$ nanoparticles: Performance and mechanism study. Appl Surf Sci 435:55-64. doi: 10.1016/j.apsusc.2017.11.084

Filip J, Karlický F, Marušák Z, Lazar P, Černík M, Otyepka M, Zbořil R (2014) Anaerobic reaction of nanoscale zerovalent iron with water: Mechanism and kinetics. J Phys Chem C 118:13817-13825. doi: $10.1021 / j p 501846 f$

Fu F, Dionysiou DD, Liu H (2014) The use of zero-valent iron for groundwater remediation and wastewater treatment: A review. J Hazard Mater 267:194-205. doi: 10.1016/j.jhazmat.2013.12.062

Gillham RW, O’Hannesin SF (1994) Enhanced degradation of halogenated aliphatics by zero-valent iron. Ground Water 32:958-967. doi: 10.1111/j.1745-6584.1994.tb00935.x

Graham LJ, Jovanovic G (1999) Dechlorination of p-chlorophenol on a $\mathrm{Pd} / \mathrm{Fe}$ catalyst in a magnetically stabilized fluidized bed; Implications for sludge and liquid remediation. Chem Eng Sci 54:3085-3093. doi: $10.1016 / \mathrm{S} 0009-2509(98) 00393-5$

Greenlee LF, Torrey JD, Amaro RL, Shaw JM (2012) Kinetics of zero valent iron nanoparticle oxidation in oxygenated water. Environ Sci Technol 46:12913-12920. doi: 10.1021/es303037k

Grieger KD, Fjordbøge A, Hartmann NB, Eriksson E, Bjerg PL, Baun A (2010) Environmental benefits and risks of zero-valent iron nanoparticles (nZVI) for in situ remediation: Risk mitigation or trade-off? J Contam Hydrol 118:165-183. doi: 10.1016/j.jconhyd.2010.07.011

Grittini C, Malcomson M, Fernando Q, Korte N (1995) Rapid dechlorination of polychlorinated biphenyls on the surface of a Pd/Fe bimetallic system. Environ Sci Technol 29:2898-2900. doi: 10.1021/es00011a029

Han J, Xin J, Zheng X, Kolditz O, Shao H (2016) Remediation of trichloroethylene-contaminated groundwater 
by three modifier-coated microscale zero-valent iron. Environ Sci Pollut Res 23:14442-14450. doi: $10.1007 / \mathrm{s} 11356-016-6368-\mathrm{z}$

550

551

552

553

554

555

556

557

558

559

560

561

562

563

564

565

566

567

568

569

570

571

572

He F, Li Z, Shi S, Xu W, Sheng H, Gu Y, Jiang Y, Xi B (2018) Dechlorination of excess trichloroethene by bimetallic and sulfidated nanoscale zero-valent iron. Environ Sci Technol 52:8627-8637. doi: 10.1021/acs.est.8B01735

He F, Zhao D (2008) Hydrodechlorination of trichloroethene using stabilized Fe-Pd nanoparticles: Reaction mechanism and effects of stabilizers, catalysts and reaction conditions. Appl Catal B Environ 84:533-540. doi: 10.1016/j.apcatb.2008.05.008

He F, Zhao D, Liu J, Roberts CB (2007) Stabilization of Fe-Pd nanoparticles with sodium carboxymethyl cellulose for enhanced transport and dechlorination of trichloroethylene in soil and groundwater. Ind Eng Chem Res 46:29-34. doi: 10.1021/ie0610896

He F, Zhao D, Paul C (2010) Field assessment of carboxymethyl cellulose stabilized iron nanoparticles for in situ destruction of chlorinated solvents in source zones. Water Res 44:2360-2370. doi: 10.1016/j.watres.2009.12.041

Heck KN, Janesko BG, Scuseria GE, Halas NJ, Wong MS (2008) Observing metal-catalyzed chemical reactions in situ using surface-enhanced raman spectroscopy on Pd-Au nanoshells. J Am Chem Soc 130:1659216600. doi: $10.1021 / \mathrm{ja} 803556 \mathrm{k}$

Herrero J, Puigserver D, Nijenhuis I, Kuntze K, Carmona JM (2019) Combined use of ISCR and biostimulation techniques in incomplete processes of reductive dehalogenation of chlorinated solvents. Sci Total Environ 648:819-829. doi: 10.1016/j.scitotenv.2018.08.184

Howard PH (1989) Handbook of Environmental Fate and Exposure Data for Organic Chemicals. CRC Press

Huang B, Isse AA, Durante C, Wei C, Gennaro A (2012) Electrocatalytic properties of transition metals toward reductive dechlorination of polychloroethanes. Electrochim Acta 70:50-61. doi: 10.1016/jelectacta.2012.03.009

Huang B, Qian W, Yu C, Wang T, Zeng G, Lei C (2016) Effective catalytic hydrodechlorination of o-, p- and mchloronitrobenzene over $\mathrm{Ni} / \mathrm{Fe}$ nanoparticles: Effects of experimental parameter and molecule structure on the reduction kinetics and mechanisms. Chem Eng J 306:607-618. doi: 10.1016/j.cej.2016.07.109 
Hunting ER, Kampfraath AA (2013) Contribution of bacteria to redox potential (Eh) measurements in sediments. Int J Environ Sci Technol 10:55-62. doi: 10.1007/s13762-012-0080-4

Jiang G, Lan M, Zhang Z, Lv X, Lou Z, Xu X, Dong F, Zhang S (2017) Identification of active hydrogen species on palladium nanoparticles for an enhanced electrocatalytic hydrodechlorination of 2,4-dichlorophenol in water. Environ Sci Technol 51:7599-7605. doi: 10.1021/acs.est.7b01128

Jiang G, Wang K, Li J, Fu W, Zhang Z, Johnson G, Lv X, Zhang Y, Zhang S, Dong F (2018) Electrocatalytic hydrodechlorination of 2,4-dichlorophenol over palladium nanoparticles and its pH-mediated tug-of-war with hydrogen evolution. Chem Eng J 348:26-34. doi: 10.1016/j.cej.2018.04.173

Kaifas D, Malleret L, Kumar N, Fétimi W, Claeys-Bruno M, Sergent M, Doumenq P (2014) Assessment of potential positive effects of nZVI surface modification and concentration levels on TCE dechlorination in the presence of competing strong oxidants, using an experimental design. Sci Total Environ 481:335-342. doi: 10.1016/j.scitotenv.2014.02.04

Kim C, Ahn J-Y, Kim TY, Shin WS, Hwang I (2018) Activation of persulfate by nanosized zero-valent iron (NZVI): Mechanisms and transformation products of NZVI. Environ Sci Technol 52:3625-3633. doi: 10.1021/acs.est.7b05847

Kim YH, Carraway ER (2003) Reductive dechlorination of TCE by zero valent bimetals. Environ Technol 24:69-75. doi: 10.1080/09593330309385537

Kocur CM, Chowdhury AI, Sakulchaicharoen N, Boparai HK, Weber KP, Sharma P, Krol MM, Austrins L, Peace C, Sleep BE, O’Carroll DM (2014) Characterization of nZVI mobility in a field scale test. Environ Sci Technol 48:2862-2869. doi: 10.1021/es4044209

Kocur CMD, Lomheim L, Molenda O, Weber KP, Austrins LM, Sleep BE, Boparai HK, Edwards EA, O’Carroll DM (2016) Long-term field study of microbial community and dechlorinating activity following carboxymethyl cellulose-stabilized nanoscale zero-valent iron injection. Environ Sci Technol 50:76587670. doi: 10.1021/acs.est.6b01745

Koenig JC, Boparai HK, Lee MJ, O’Carroll DM, Barnes RJ, Manefield MJ (2016) Particles and enzymes: Combining nanoscale zero valent iron and organochlorine respiring bacteria for the detoxification of chloroethane mixtures. J Hazard Mater 308:106-112. doi: 10.1016/j.jhazmat.2015.12.036 
Kumar N, Auffan M, Gattacceca J, Rose J, Olivi L, Borschneck D, Kvapil P, Jublot M, Kaifas D, Malleret L, Doumenq P, Bottero J-Y (2014) Molecular insights of oxidation process of iron nanoparticles: Spectroscopic, magnetic, and microscopic evidence. Environ Sci Technol 48:13888-13894. doi: $10.1021 / \mathrm{es} 503154 \mathrm{q}$

Kumar N, Labille J, Bossa N, Auffan M, Doumenq P, Rose J, Bottero J-Y (2017) Enhanced transportability of zero valent iron nanoparticles in aquifer sediments: Surface modifications, reactivity, and particle traveling distances. Environ Sci Pollut Res 24:9269-9277. doi: 10.1007/s11356-017-8597-1

Lee C, Kim JY, Lee W Il, Nelson KL, Yoon J, Sedlak DL (2008) Bactericidal effect of zero-valent iron nanoparticles on Escherichia coli. Environ Sci Technol 42:4927-4933. doi: 10.1021/es800408u

Lien H-L, Zhang W (2007) Nanoscale Pd/Fe bimetallic particles: Catalytic effects of palladium on hydrodechlorination. Appl Catal B Environ 77:110-116. doi: 10.1016/j.apcatb.2007.07.014

Lien H-L, Zhang W (1999) Transformation of chlorinated methanes by nanoscale iron particles. J Environ Eng 125:1042-1047. doi: 10.1061/(ASCE)0733-9372(1999)125:11(1042)

Lien H-L, Zhang W (2005) Hydrodechlorination of chlorinated ethanes by nanoscale Pd/Fe bimetallic particles. J Environ Eng 131:4-10. doi: 10.1061/(ASCE)0733-9372(2005)131:1(4)

Lin CJ, Lo S-L (2005) Effects of iron surface pretreatment on sorption and reduction kinetics of trichloroethylene in a closed batch system. Water Res 39:1037-1046. doi: 10.1016/j.watres.2004.06.035

Ling L, Huang X, Li M, Zhang W (2017) Mapping the reactions in a single zero-valent iron nanoparticle. Environ Sci Technol 51:14293-14300. doi: 10.1021/acs.est.7b02233

Ling L, Zhang W (2014) Structures of Pd-Fe(0) Bimetallic nanoparticles near $0.1 \mathrm{~nm}$ resolution. RSC Adv 4:33861. doi: 10.1039/C4RA04311A

Liu A, Liu J, Han J, Zhang W (2017) Evolution of nanoscale zero-valent iron (nZVI) in water: Microscopic and spectroscopic evidence on the formation of nano- and micro-structured iron oxides. J Hazard Mater 322:129-135. doi: 10.1016/j.jhazmat.2015.12.070

Liu A, Liu J, Pan B, Zhang W (2014a) Formation of lepidocrocite ( $\gamma$-FeOOH) from oxidation of nanoscale zerovalent iron (nZVI) in oxygenated water. RSC Adv 4:57377-57382. doi: 10.1039/C4RA08988J 
Liu A, Zhang W (2014) Fine structural features of nanoscale zero-valent iron characterized by spherical aberration corrected scanning transmission electron microscopy (Cs-STEM). Analyst 139:4512-4518. doi: 10.1039/C4AN00679H

Liu R, Zhao H, Zhao X, He Z, Lai Y, Shan W, Bekana D, Li G, Liu J (2018) Defect sites in ultrathin Pd nanowires facilitate the highly efficient electrochemical hydrodechlorination of pollutants by $\mathrm{H}^{*}$ ads. Environ Sci Technol 52:9992-10002. doi: 10.1021/acs.est.8b02740

Liu W-J, Qian T-T, Jiang H (2014b) Bimetallic Fe nanoparticles: Recent advances in synthesis and application in catalytic elimination of environmental pollutants. Chem Eng J 236:448-463. doi: 10.1016/j.cej.2013.10.062

Liu Y, Lowry G V. (2006) Effect of particle age (Fe0 content) and solution pH on NZVI reactivity: H2 evolution and TCE dechlorination. Environ Sci Technol 40:6085-6090. doi: 10.1021/es060685o

Louie SM, Tilton RD, Lowry G V (2016) Critical review: Impacts of macromolecular coatings on critical physicochemical processes controlling environmental fate of nanomaterials. Environ Sci Nano 3:283-310. doi: 10.1039/C5EN00104H

Lowry G V, Reinhard M (1999) Hydrodehalogenation of 1- to 3-carbon halogenated organic compounds in water using a palladium catalyst and hydrogen gas. Environ Sci Technol 33:1905-1910. doi: $10.1021 / \mathrm{es} 980963 \mathrm{~m}$

Martin JE, Herzing AA, Yan W, Li X, Koel BE, Kiely CJ, Zhang W (2008) Determination of the oxide layer thickness in core-shell zerovalent iron nanoparticles. Langmuir 24:4329-4334. doi: 10.1021/la703689K

Mu Y, Jia F, Ai Z, Zhang L (2017) Iron oxide shell mediated environmental remediation properties of nano zerovalent iron. Environ Sci Nano 4:27-45. doi: 10.1039/C6EN00398B

Muftikian R, Nebesny K, Fernando Q, Korte N (1996) X-ray photoelectron spectra of the palladium-iron bimetallic surface used for the rapid dechlorination of chlorinated organic environmental contaminants. Environ Sci Technol 30:3593-3596. doi: 10.1021/es960289D

Noubactep C (2008) A critical review on the process of contaminant removal in $\mathrm{Fe} 0-\mathrm{H} 2 \mathrm{O}$ systems. Environ Technol 29:909-920. doi: 10.1080/09593330802131602 
Noubactep C, Caré S, Crane R (2012) Nanoscale metallic iron for environmental remediation: Prospects and limitations. Water Air Soil Pollut 223:1363-1382. doi: 10.1007/s11270-011-0951-1

Nurmi JT, Tratnyek PG, Sarathy V, Baer DR, Amonette JE, Pecher K, Wang C, Linehan JC, Matson DW, Penn RL, Driessen MD (2005) Characterization and properties of metallic iron nanoparticles: Spectroscopy, electrochemistry, and kinetics. Environ Sci Technol 39:1221-1230. doi: 10.1021/es049190U

O’Hannesin SF, Gillham RW (1998) Long-term performance of an in situ "iron wall” for remediation of VOCs. Ground Water 36:164-170. doi: 10.1111/j.1745-6584.1998.tb01077.x

O 'Carroll D, Sleep B, Krol M, Boparai H, Kocur C (2013) Nanoscale zero valent iron and bimetallic particles for contaminated site remediation. Adv Water Resour 51:104-122. doi: 10.1016/j.advwatres.2012.02.005

Papaderakis A, Tsiplakides D, Balomenou S, Sotiropoulos S (2017) Probing the hydrogen adsorption affinity of Pt and Ir by surface interrogation scanning electrochemical microscopy (SI-SECM). Electrochem Commun 83:77-80. doi: 10.1016/j.elecom.2017.09.003

Patterson E V., Cramer CJ, Truhlar DG (2001) Reductive dechlorination of hexachloroethane in the environment: Mechanistic studies via computational electrochemistry. J Am Chem Soc 123:2025-2031. doi: $10.1021 / \mathrm{ja} 0035349$

Phenrat T, Liu Y, Tilton RD, Lowry G V (2009) Adsorbed polyelectrolyte coatings decrease Fe(0) nanoparticle reactivity with TCE in water: Conceptual model and mechanisms. Environ Sci Technol 43:1507-14. doi: $10.1021 /$ es $802187 d$

Phenrat T, Saleh N, Sirk K, Kim H-J, Tilton RD, Lowry G V. (2008) Stabilization of aqueous nanoscale zerovalent iron dispersions by anionic polyelectrolytes: Adsorbed anionic polyelectrolyte layer properties and their effect on aggregation and sedimentation. J Nanoparticle Res 10:795-814. doi: 10.1007/s11051007-9315-6

Pierro L, Matturro B, Rossetti S, Sagliaschi M, Sucato S, Alesi E, Bartsch E, Arjmand F, Papini MP (2017) Polyhydroxyalkanoate as a slow-release carbon source for in situ bioremediation of contaminated aquifers: from laboratory investigation to pilot-scale testing in the field. $\mathrm{N}$ Biotechnol 37:60-68. doi: 10.1016/j.nbt.2016.11.004 
Pizarro S, Araya M, Delgadillo A (2018) Hexachloroethane reduction catalyzed by cobaloximes. Effect of the substituents on the equatorial ligands. Polyhedron 141:94-99. doi: 10.1016/j.poly.2017.11.005

Reddy AVB, Yusop Z, Jaafar J, Reddy YVM, Aris A Bin, Majid ZA, Talib J, Madhavi G (2016) Recent progress on Fe-based nanoparticles: Synthesis, properties, characterization and environmental applications. J Environ Chem Eng 4:3537-3553. doi: 10.1016/j.jece.2016.07.035

Reddy KR, Khodadoust AP, Darko-Kagya K (2014) Transport and reactivity of lactate-modified nanoscale iron particles for remediation of DNT in subsurface soils. J Environ Eng 140:04014042. doi: 10.1061/(ASCE)EE.1943-7870.0000870

Rodrigues R, Betelu S, Colombano S, Masselot G, Tzedakis T, Ignatiadis I (2017a) Reductive dechlorination of hexachlorobutadiene by a $\mathrm{Pd} / \mathrm{Fe}$ microparticle suspension in dissolved lactic acid polymers: Degradation mechanism and kinetics. Ind Eng Chem Res 56:12092-12100. doi: 10.1021/acs.iecr.7b03012

Rodrigues R, Betelu S, Colombano S, Masselot G, Tzedakis T, Ignatiadis I (2017b) Influence of temperature and surfactants on the solubilization of hexachlorobutadiene and hexachloroethane. J Chem Eng Data 62:32523260. doi: 10.1021/acs.jced.7b00320

Sabot R, Jeannin M, Gadouleau M, Guo Q, Sicre E, Refait P (2007) Influence of lactate ions on the formation of rust. Corros Sci 49:1610-1624. doi: 10.1016/j.corsci.2006.10.004

Sarathy V, Tratnyek PG, Nurmi JT, Baer DR, Amonette JE, Chun CL, Penn RL, Reardon EJ (2008) Aging of iron nanoparticles in aqueous solution: Effects on structure and reactivity. J Phys Chem C 112:2286-2293. doi: $10.1021 / j p 0777418$

Schöftner P, Waldner G, Lottermoser W, Stöger-Pollach M, Freitag P, Reichenauer TG (2015) Electron efficiency of nZVI does not change with variation of environmental parameters. Sci Total Environ 535:6978. doi: 10.1016/j.scitotenv.2015.05.033

Shi Z, Fan D, Johnson RL, Tratnyek PG, Nurmi JT, Wu Y, Williams KH (2015) Methods for characterizing the fate and effects of nano zerovalent iron during groundwater remediation. J Contam Hydrol 181:17-35. doi: 10.1016/j.jconhyd.2015.03.004

Shi Z, Nurmi JT, Tratnyek PG (2011) Effects of nano Zero-valent iron on oxidation-reduction potential. Environ Sci Technol 45:1586-1592. doi: 10.1021/es103185t 
Shih Y, Chen M-Y, Su Y-F (2011) Pentachlorophenol reduction by Pd/Fe bimetallic nanoparticles: Effects of copper, nickel, and ferric cations. Appl Catal B Environ 105:24-29. doi: 10.1016/j.apcatb.2011.03.024

Song H, Carraway ER (2005) Reduction of chlorinated ethanes by nanosized zero-valent iron: Kinetics, pathways, and effects of reaction conditions. Environ Sci Technol 39:6237-6245. doi: 10.1021/es048262e

Sriwatanapongse W, Reinhard M, Klug CA (2006) Reductive hydrodechlorination of trichloroethylene by palladium-on-alumina catalyst: $13 \mathrm{C}$ solid-state NMR study of surface reaction precursors. Langmuir 22:4158-4164. doi: 10.1021/la053087g

Stefaniuk M, Oleszczuk P, Ok YS (2016) Review on nano zerovalent iron (nZVI): From synthesis to environmental applications. Chem Eng J 287:618-632. doi: 10.1016/j.cej.2015.11.046

Stringer R, Johnston P (2001) Chlorine and the Environment: An Overview of the Chlorine Industry. Kluwer Academic Publishers

Sun Y-P, Li X, Cao J, Zhang W, Wang HP (2006) Characterization of zero-valent iron nanoparticles. Adv Colloid Interface Sci 120:47-56. doi: 10.1016/j.cis.2006.03.001

Sun Y, Li J, Huang T, Guan X (2016) The influences of iron characteristics, operating conditions and solution chemistry on contaminants removal by zero-valent iron: A review. Water Res 100:277-295. doi: 10.1016/j.watres.2016.05.031

Tang F, Xin J, Zheng X, Zheng T, Yuan X, Kolditz O (2017a) Effect of solution pH on aging dynamics and Surface structural evolution of mZVI particles: $\mathrm{H} 2$ production and spectroscopic/microscopic evidence. Environ Sci Pollut Res 1-11. doi: 10.1007/s11356-017-9976-3

Tang S, Wang X, Liu S, Yang H, Xie YF, Yang X (2017b) Mechanism and kinetics of halogenated compound removal by metallic iron: Transport in solution, diffusion and reduction within corrosion films. Chemosphere 178:119-128. doi: 10.1016/j.chemosphere.2017.03.006

Tosco T, Papini MP, Cruz Viggi C, Sethi R (2014) Nanoscale zerovalent iron particles for groundwater remediation: A review. J Clean Prod 77:10-21. doi: 10.1016/j.jclepro.2013.12.026

Velimirovic M, Auffan M, Carniato L, Batka VM, Schmid D, Wagner S, Borschneck D, Proux O, von der Kammer F, Hofmann T (2018) Effect of field site hydrogeochemical conditions on the corrosion of milled 
zerovalent iron particles and their dechlorination efficiency. Sci Total Environ 618:1619-1627. doi: 10.1016/j.scitotenv.2017.10.002

Velimirovic M, Carniato L, Simons Q, Schoups G, Seuntjens P, Bastiaens L (2014) Corrosion rate estimations of microscale zerovalent ironparticles via direct hydrogen production measurements. J Hazard Mater 270:1826. doi: 10.1016/j.jhazmat.2014.01.034

Velimirovic M, Chen H, Simons Q, Bastiaens L (2012) Reactivity recovery of guar gum coupled mZVI by means of enzymatic breakdown and rinsing. $\mathrm{J}$ Contam Hydrol 142-143:1-10. doi: 10.1016/j.jconhyd.2012.09.003

Velimirovic M, Larsson P-O, Simons Q, Bastiaens L (2013a) Reactivity screening of microscale zerovalent irons and iron sulfides towards different CAHs under standardized experimental conditions. J Hazard Mater 252-253:204-212. doi: 10.1016/j.jhazmat.2013.02.047

Velimirovic M, Larsson P-O, Simons Q, Bastiaens L (2013b) Impact of carbon, oxygen and sulfur content of microscale zerovalent iron particles on its reactivity towards chlorinated aliphatic hydrocarbons. Chemosphere 93:2040-2045. doi: 10.1016/j.chemosphere.2013.07.034

Velimirovic M, Simons Q, Bastiaens L (2015) Use of CAH-degrading bacteria as test-organisms for evaluating the impact of fine zerovalent iron particles on the anaerobic subsurface environment. Chemosphere 134:338-345. doi: 10.1016/j.chemosphere.2015.04.068

Voogt EH, Mens AJM, Gijzeman OLJ, Geus JW (1996) XPS analysis of palladium oxide layers and particles. Surf Sci 350:21-31. doi: 10.1016/0039-6028(96)01028-X

Wang J, Chu L (2016) Biological nitrate removal from water and wastewater by solid-phase denitrification process. Biotechnol Adv 34:1103-1112. doi: 10.1016/j.biotechadv.2016.07.001

Wang X, Chen C, Chang Y, Liu H (2009) Dechlorination of chlorinated methanes by Pd/Fe bimetallic nanoparticles. J Hazard Mater 161:815-823. doi: 10.1016/j.jhazmat.2008.04.027

Wei Y-T, Wu S-C, Chou C-M, Che C-H, Tsai S-M, Lien H-L (2010) Influence of nanoscale zero-valent iron on geochemical properties of groundwater and vinyl chloride degradation: A field case study. Water Res 44:131-140. doi: 10.1016/j.watres.2009.09.012 
Wei Y-T, Wu S, Yang S-W, Che C-H, Lien H-L, Huang D-H (2012) Biodegradable surfactant stabilized nanoscale zero-valent iron for in situ treatment of vinyl chloride and 1,2-dichloroethane. J Hazard Mater 211-212:373-380. doi: 10.1016/j.jhazmat.2011.11.018

Wu DL, Liu YX, Liu ZG, Ma LM (2014) Dechlorination of hexachloroethane in water using iron shavings and amended iron shavings: Kinetics and pathways. J Chem 2014:1-9. doi: 10.1155/2014/325879

Xie Y, Cwiertny DM (2013) Chlorinated solvent transformation by palladized zerovalent iron: Mechanistic insights from reductant loading studies and solvent kinetic isotope effects. Environ Sci Technol 47:79407948. doi: $10.1021 / \mathrm{es} 401481 \mathrm{a}$

Xu Y, Wang C, Hou J, Wang P, You G, Miao L, Lv B, Yang Y, Zhang F (2017) Application of zero valent iron coupling with biological process for wastewater treatment: A review. Rev Environ Sci Bio/Technology 127. doi: $10.1007 / \mathrm{s} 11157-017-9445-\mathrm{y}$

Yan W, Herzing AA, Li X, Kiely CJ, Zhang W (2010) Structural evolution of Pd-doped nanoscale zero-valent iron (nZVI) in aqueous media and implications for particle aging and reactivity. Environ Sci Technol 44:4288-4294. doi: 10.1021/es100051q

Yan W, Lien H-L, Koel BE, Zhang W (2013) Iron nanoparticles for environmental clean-up: Recent developments and future putlook. Environ Sci Process Impacts 15:63-77. doi: 10.1039/C2EM30691C

Yang Y, Cápiro NL, Marcet TF, Yan J, Pennell KD, Löffler FE (2017a) Organohalide respiration with chlorinated ethenes under low pH conditions. Environ Sci Technol 51:8579-8588. doi: 10.1021/acs.est.7b01510

Yang Y, Cápiro NL, Yan J, Marcet TF, Pennell KD, Löffler FE (2017b) Resilience and recovery of dehalococcoides mecartyi following low pH exposure. FEMS Microbiol Ecol 93:fix130. doi: 10.1093/femsec/fix130

Yu R-F, Chi F-H, Cheng W-P, Chang J-C (2014) Application of pH, ORP, and DO monitoring to evaluate chromium(VI) removal from wastewater by the nanoscale zero-valent iron (nZVI) process. Chem Eng $\mathbf{J}$ 255:568-576. doi: 10.1016/j.cej.2014.06.002

Zhang W (2003) Nanoscale iron particles for environmental remediation: An overview. J Nanoparticle Res 5:323-332. doi: 10.1023/A:1025520116015 
Zhao X, Liu W, Cai Z, Han B, Qian T, Zhao D (2016) An overview of preparation and applications of stabilized zero-valent iron nanoparticles for soil and groundwater remediation. Water Res 100:245-266. doi: 10.1016/j.watres.2016.05.019

Zhu B-W, Lim T-T, Feng J (2008) Influences of amphiphiles on dechlorination of a trichlorobenzene by nanoscale Pd/Fe: Adsorption, reaction kinetics, and interfacial interactions. Environ Sci Technol 42:45134519. doi: 10.1021/es800227r

Zhu C, Zhu F, Liu C, Chen N, Zhou D, Fang G, Gao J (2018) Reductive hexachloroethane degradation by S2O8•- with thermal activation of persulfate under anaerobic conditions. Environ Sci Technol 52:85488557. doi: 10.1021/acs.est.7b06279 
Table 1 Pseudo-first order rate constants for HCA degradation under the different experimental conditions

799 (effects of Pd-mZVI dosage, temperature, HCA initial concentration and PLA content)

\begin{tabular}{cccccc}
\hline $\begin{array}{c}\text { Figure } \\
\text { number }\end{array}$ & $\begin{array}{c}m_{\mathrm{Pd}-\mathrm{mZVI}} \\
(\mathrm{mg})\end{array}$ & $\begin{array}{c}T \\
\left({ }^{\circ} \mathrm{C}\right)\end{array}$ & $\begin{array}{c}{[\mathrm{HCA}]_{0}} \\
\left(\mathrm{mg} \mathrm{L}^{-1}\right)\end{array}$ & $\begin{array}{c}m_{\mathrm{PLA}} \\
(\mathrm{mg})\end{array}$ & $\begin{array}{c}k_{\mathrm{obs}}(\mathrm{Eq} .12) \\
\left(\mathrm{min}^{-1}\right)\end{array}$ \\
\hline 4 & 150 & 25 & 10 & 850 & $0.002\left(R^{2}=0.474\right)$ \\
$4,5,6,7$ & 600 & 25 & 10 & 850 & $0.035\left(R^{2}=0.975\right)$ \\
\hline \multirow{2}{*}{5} & 600 & 12 & 10 & 850 & $0.004\left(R^{2}=0.970\right)$ \\
& 600 & 35 & 10 & 850 & $0.093\left(R^{2}=0.939\right)$ \\
\hline \multirow{2}{*}{6} & 600 & 25 & 5 & 850 & $0.036\left(R^{2}=0.940\right)$ \\
& 600 & 25 & 20 & 850 & $0.010\left(R^{2}=0.972\right)$ \\
\hline \multirow{2}{*}{7} & 600 & 25 & 10 & 1700 & $0.030\left(R^{2}=0.938\right)$ \\
& 600 & 25 & 10 & 3400 & $0.025\left(R^{2}=0.951\right)$ \\
\hline
\end{tabular}

800 


\section{List of figures}
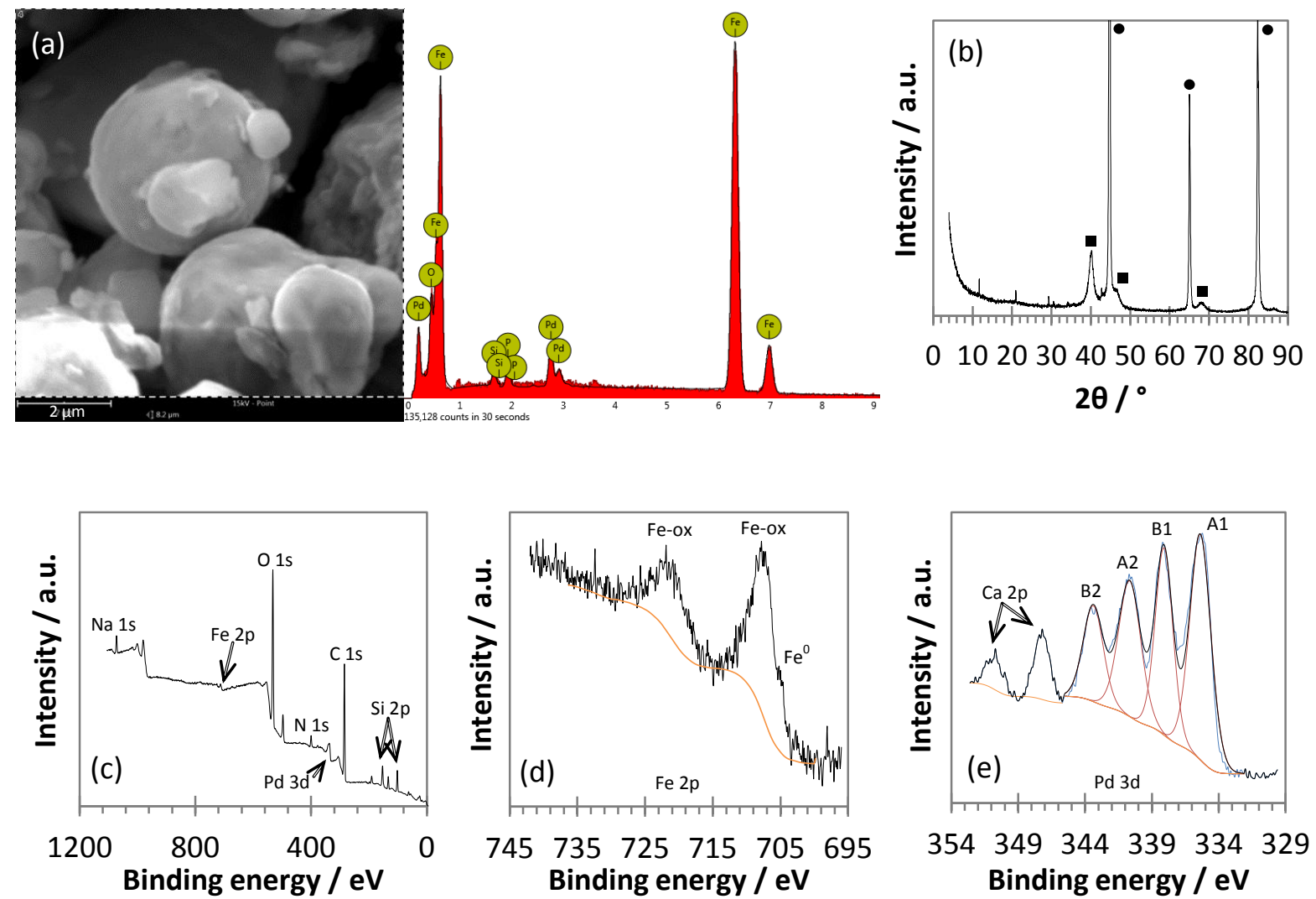

804

Fig. 1 Characterization of Pd-mZVI particles before reaction. (a) SEM image with EDS spectrum. The atomic concentration in the entire area is: $\mathrm{Fe}=77.4 \%, \mathrm{O}=16.3 \%, \mathrm{Pd}=3.3 \%, \mathrm{P}=1.8 \%, \mathrm{Si}=1.2 \%$; (b) $\mathrm{X}$-ray

806 diffraction pattern, where solid circles and squares represent $\mathrm{Fe}^{0}$ and $\mathrm{Pd}^{0}$, respectively; X-ray photoelectron spectra: (c) Survey scan, (d) Fe 2p, (e) Pd 3d 

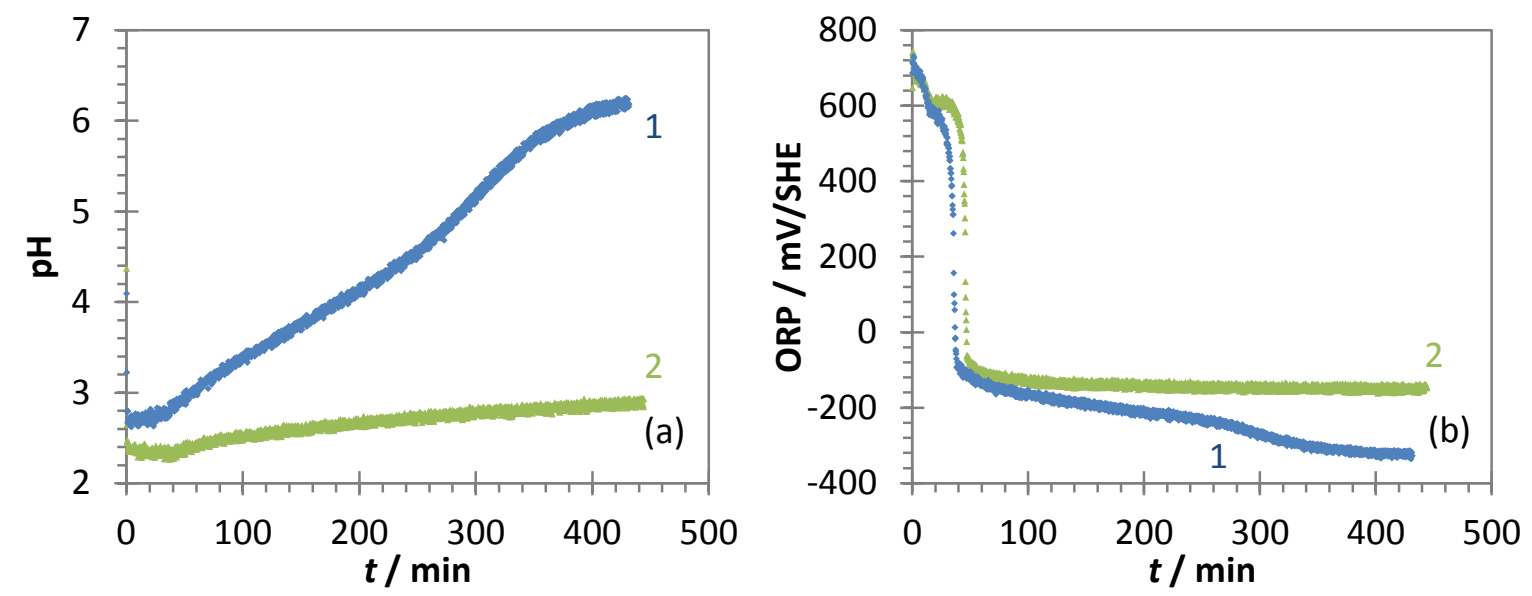

808
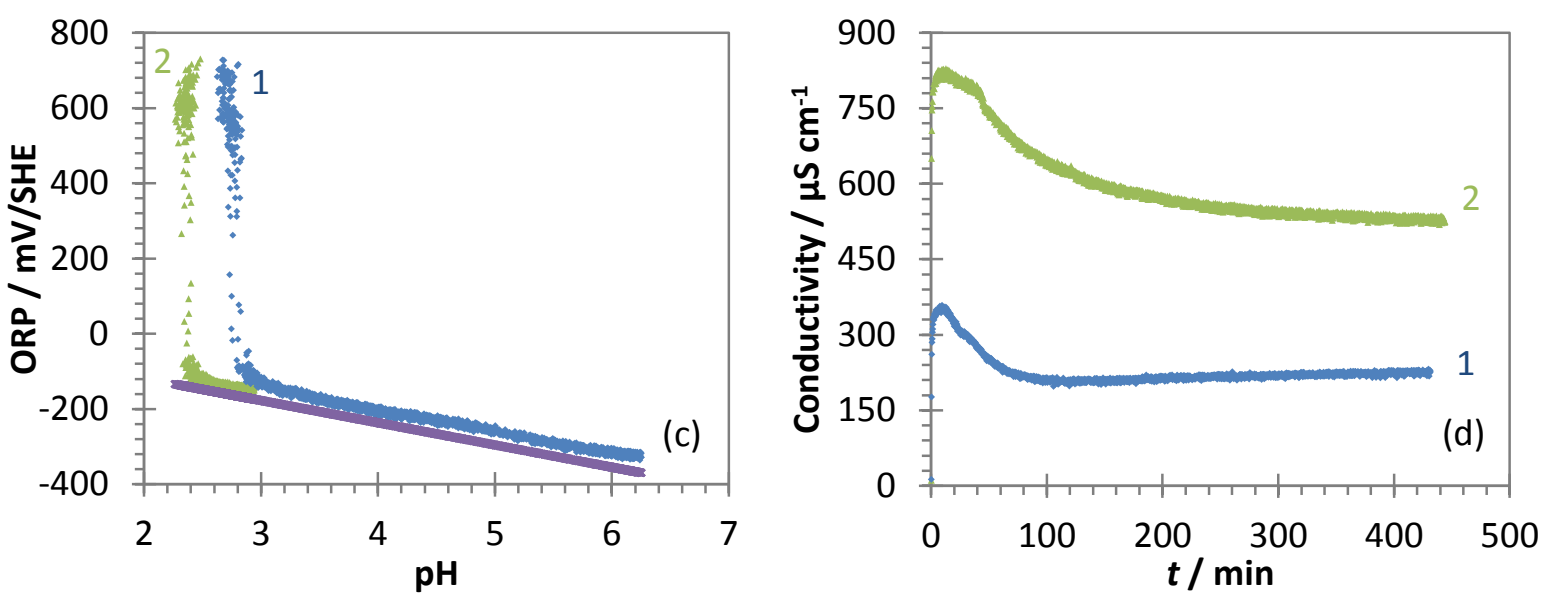

809

810

$\diamond(1)=850 \mathrm{mg}$ PLA, $\triangle(2)=3400 \mathrm{mg}$ PLA,$\times=\mathrm{H}^{+} / \mathrm{H}_{2}$ redox couple

811 Fig. 2 Monitoring of the aqueous corrosion in the Pd-mZVI/PLA/ $\mathrm{H}_{2} \mathrm{O}$ system without opening of the reactor.

812 (a) Evolution of $\mathrm{pH}$ with time, (b) Evolution of ORP with time, (c) Evolution of ORP with pH, (d) Evolution of

813 conductivity with time. Experimental conditions: $m_{\mathrm{Pd}-\mathrm{mZVI}}=600 \mathrm{mg}, T=25^{\circ} \mathrm{C}$ 

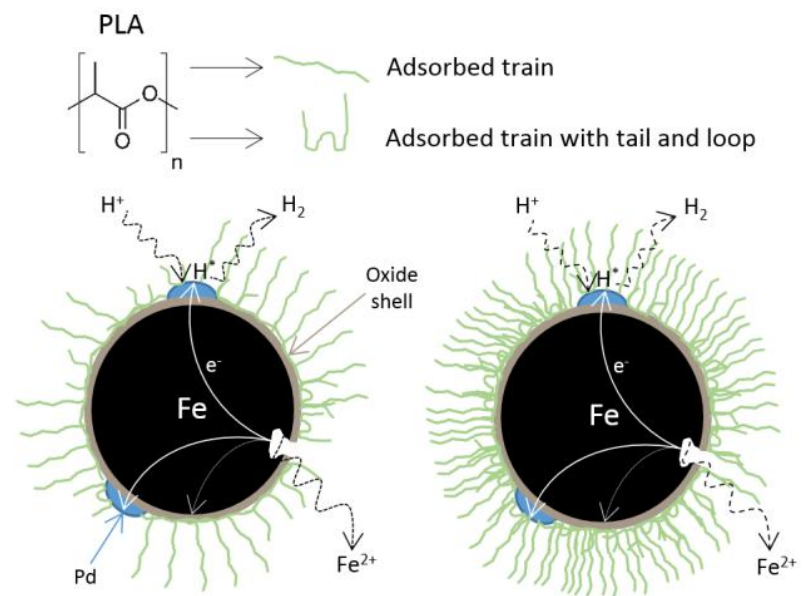

815 Fig. 3 Schematic illustration of the Pd-mZVI/PLA/ $\mathrm{H}_{2} \mathrm{O}$ system, with $850 \mathrm{mg}$ (left) and $3400 \mathrm{mg}$ (right) of PLA.

816 Depending on the adsorbed PLA on the surface, it is represented mainly as adsorbed train or as an extended layer 817 of adsorbed train with tails and loops. 

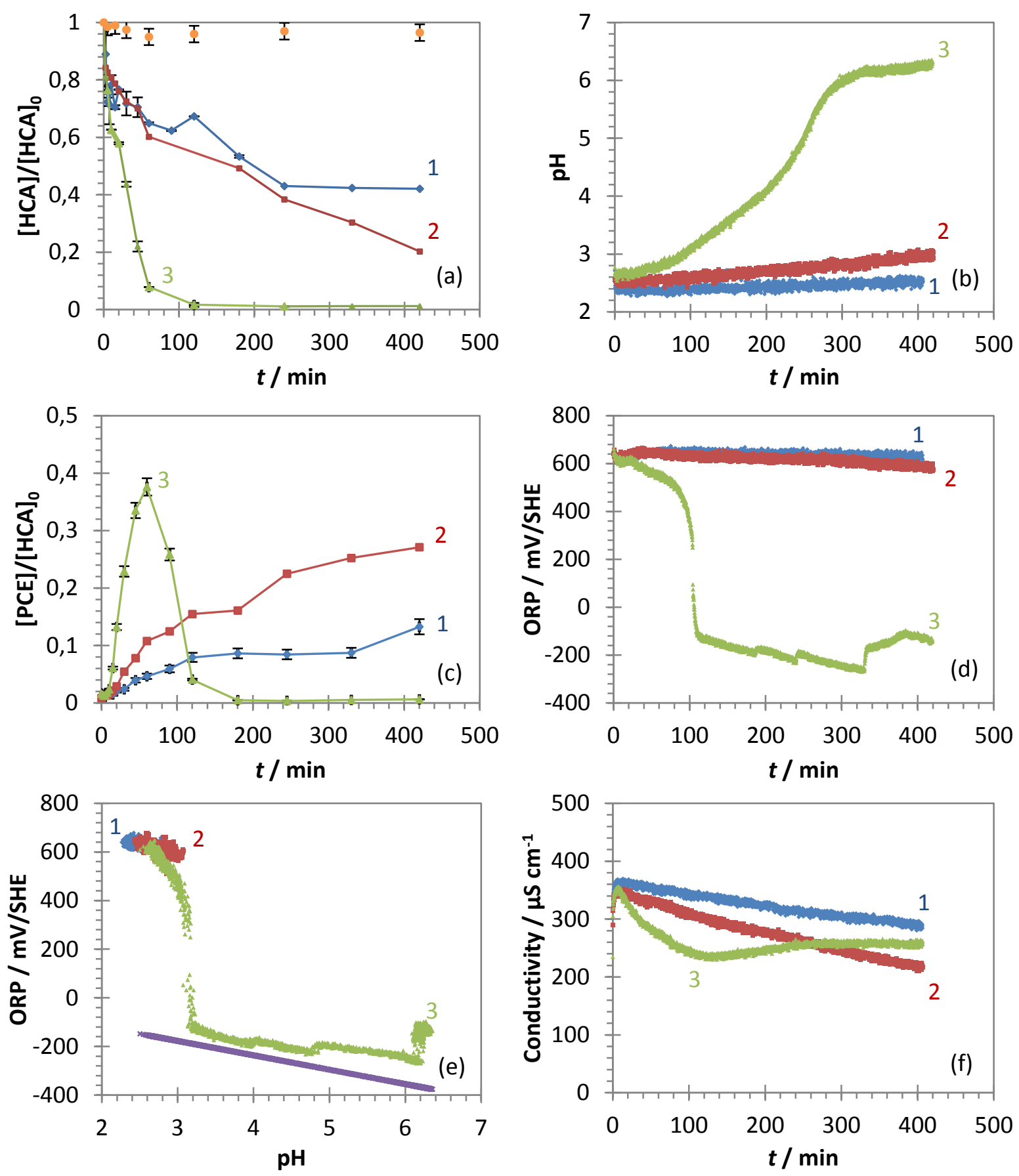

820 (1) = 150 mg Pd-mZVI, $\square(2)=375$ mg Pd-mZVI,

$\Delta(3)=600 \mathrm{mg}$ Pd-mZVI, $\bigcirc$ blank, $\times=\mathrm{H}^{+} / \mathrm{H}_{2}$ redox couple

822 Fig. 4 Effects of Pd-mZVI dosage on HCA dechlorination in the Pd-mZVI/PLA/HCA/H ${ }_{2} \mathrm{O}$ system. (a) Evolution

823 of HCA concentration with time, (b) Evolution of $\mathrm{pH}$ with time, (c) Evolution of PCE concentration with time,

824 (d) Evolution of ORP with time, (e) Evolution of ORP with pH, (f) Evolution of conductivity with time.

825 Experimental conditions: $[\mathrm{HCA}]_{0}=10 \mathrm{mg} \mathrm{L}^{-1}, m_{\mathrm{PLA}}=850 \mathrm{mg}, T=25{ }^{\circ} \mathrm{C}$. Error bars in parts a and c represent 826 standard deviation for $n=2$ 

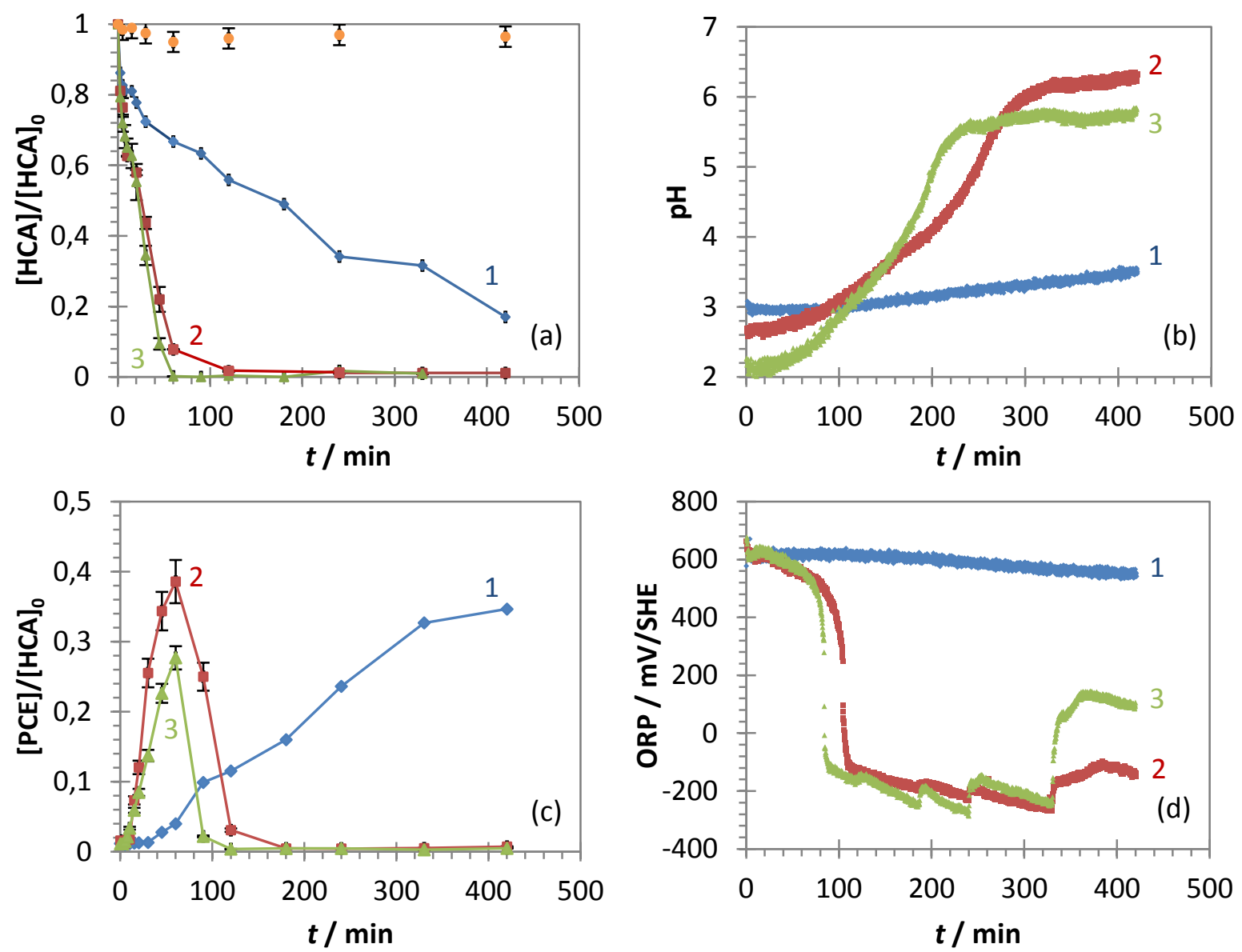

828
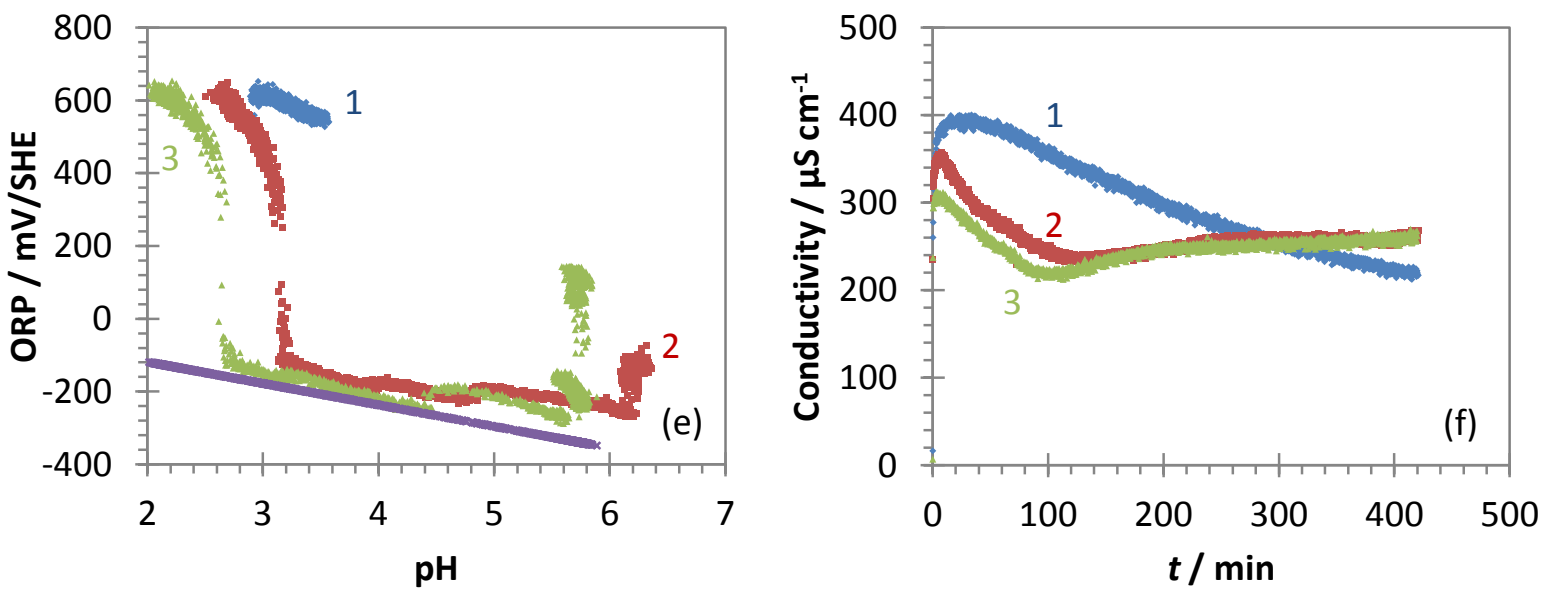

830 $\bullet(1)=12{ }^{\circ} \mathrm{C}, \boldsymbol{\square}(2)=25^{\circ} \mathrm{C}, \Delta(3)=35^{\circ} \mathrm{C}$,

${ }^{\circ} \mathrm{C}, \bullet=$ blank, $\times=\mathrm{H}^{+} / \mathrm{H}_{2}$ redox couple

831

Fig. 5 Effects of temperature on HCA dechlorination in the Pd-mZVI/PLA/HCA/ $\mathrm{H}_{2} \mathrm{O}$ system. (a) Evolution of HCA concentration with time, (b) Evolution of $\mathrm{pH}$ with time, (c) Evolution of PCE concentration with time, (d)

833 Evolution of ORP with time, (e) Evolution of ORP with $\mathrm{pH}$, (f) Evolution of conductivity with time.

834 Experimental conditions: $[\mathrm{HCA}]_{0}=10 \mathrm{mg} \mathrm{L}{ }^{-1}, m_{\mathrm{Pd}-\mathrm{mZVI}}=600 \mathrm{mg}, m_{\mathrm{PLA}}=850 \mathrm{mg}$. Error bars in parts a and c represent standard deviation for $n=2$ 

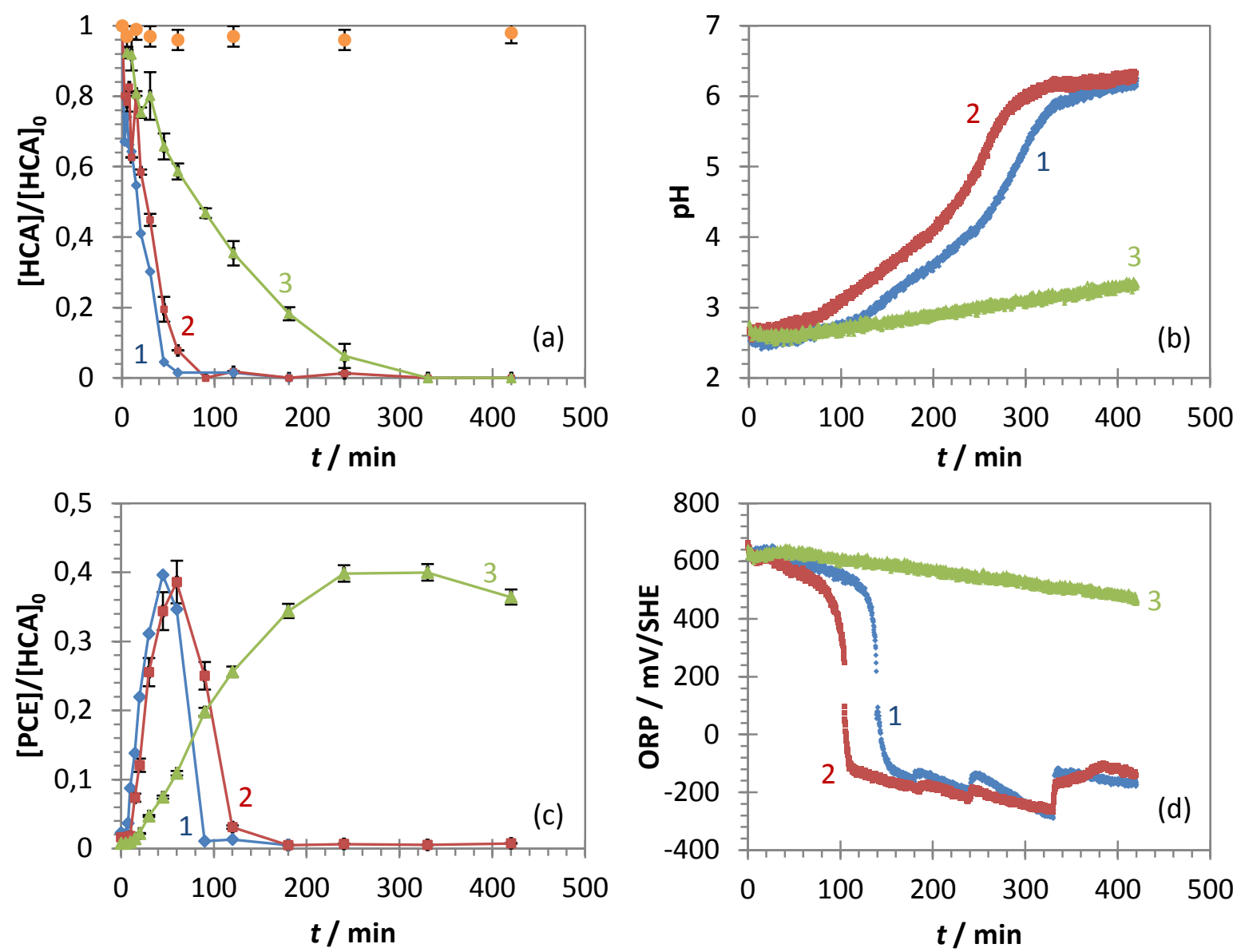

837
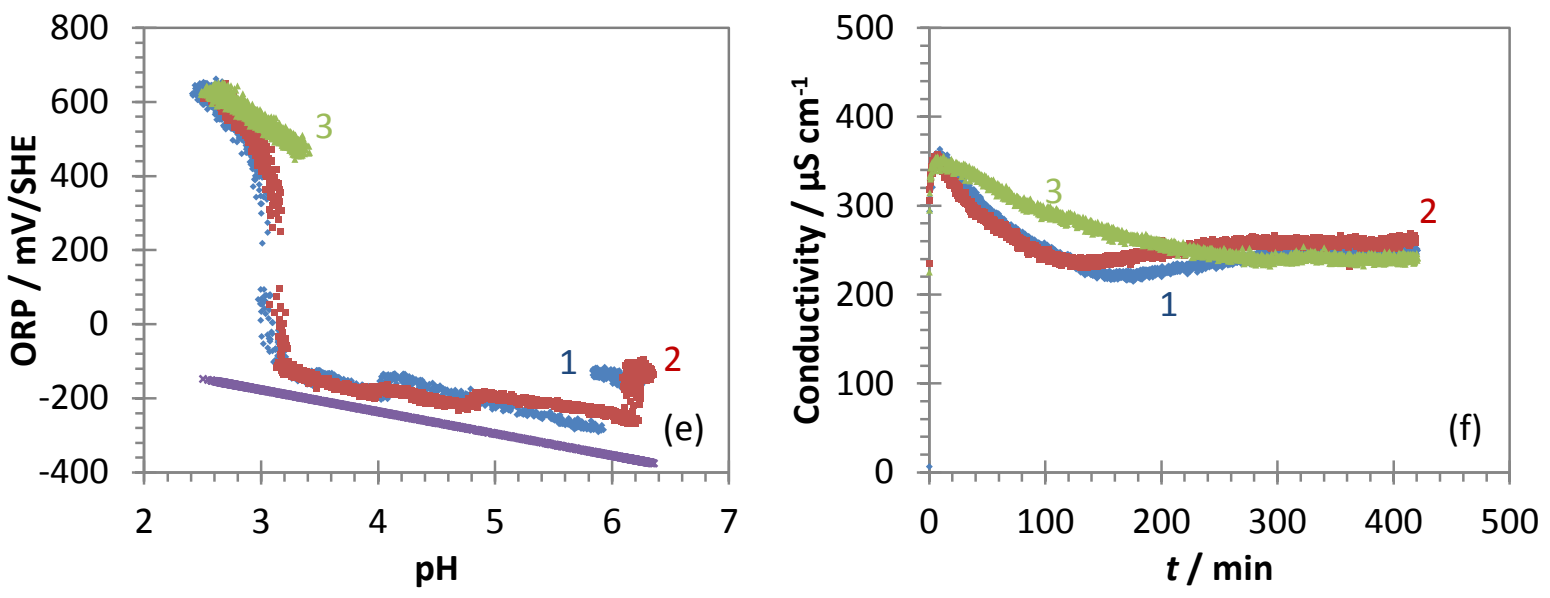

839 (1) $=5 \mathrm{mg} \mathrm{L}^{-1}$, 口 (2) $=10 \mathrm{mg} \mathrm{L}^{-1}, \Delta(3)=20 \mathrm{mg} \mathrm{L}^{-1}, \bullet=$ blank, $x=\mathrm{H}^{+} / \mathrm{H}_{2}$ redox couple

Fig. 6 Effects of initial HCA concentration on its dechlorination in the Pd-mZVI/PLA/HCA/ $\mathrm{H}_{2} \mathrm{O}$ system. (a)

841 Evolution of HCA concentration with time, (b) Evolution of $\mathrm{pH}$ with time, (c) Evolution of PCE concentration

842 with time, (d) Evolution of ORP with time, (e) Evolution of ORP with pH, (f) Evolution of conductivity with

843 time. Experimental conditions: $m_{\mathrm{Pd}-\mathrm{mZVI}}=600 \mathrm{mg}, m_{\mathrm{PLA}}=850 \mathrm{mg}, T=25{ }^{\circ} \mathrm{C}$. Error bars in parts a and c represent standard deviation for $n=2$ 

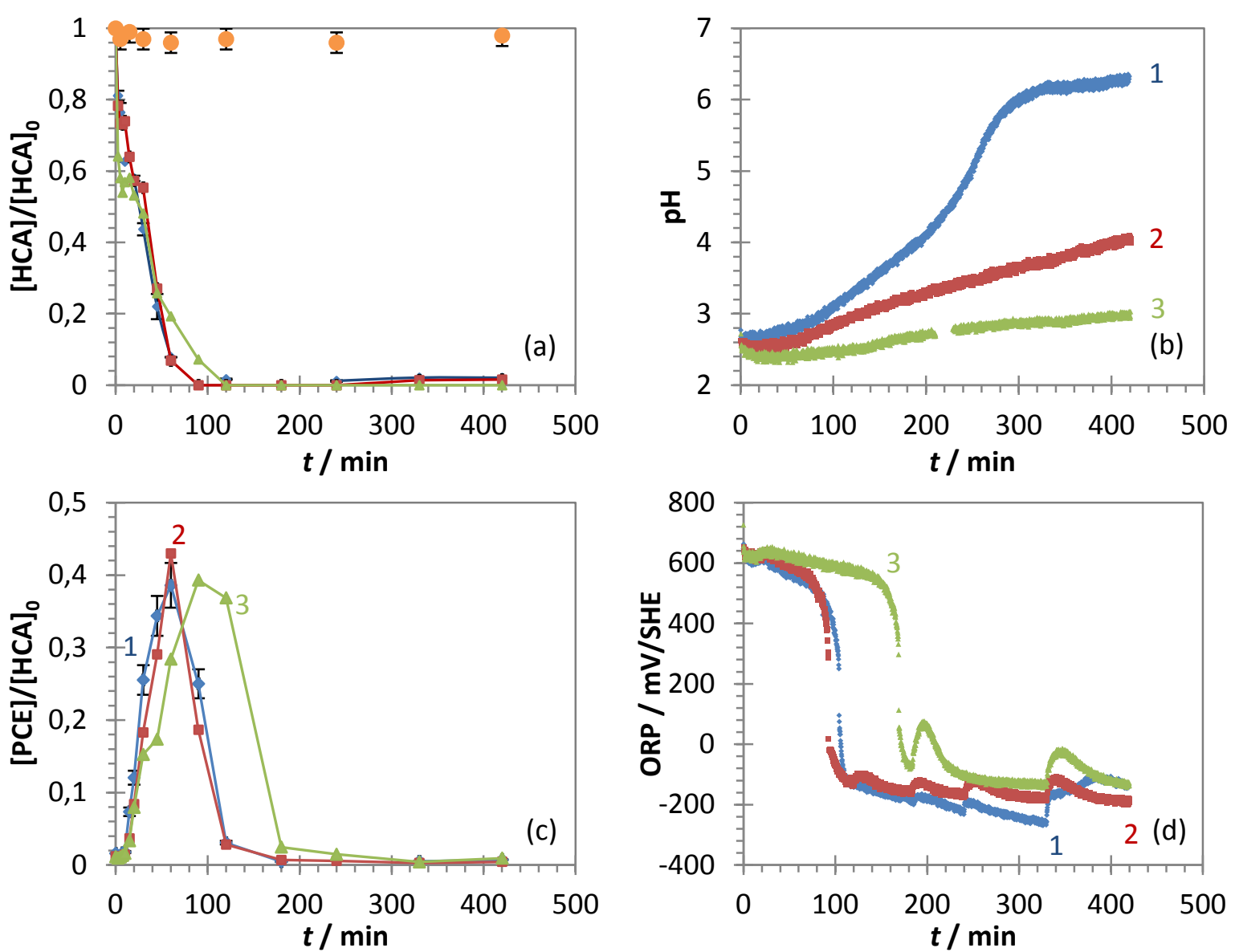

846
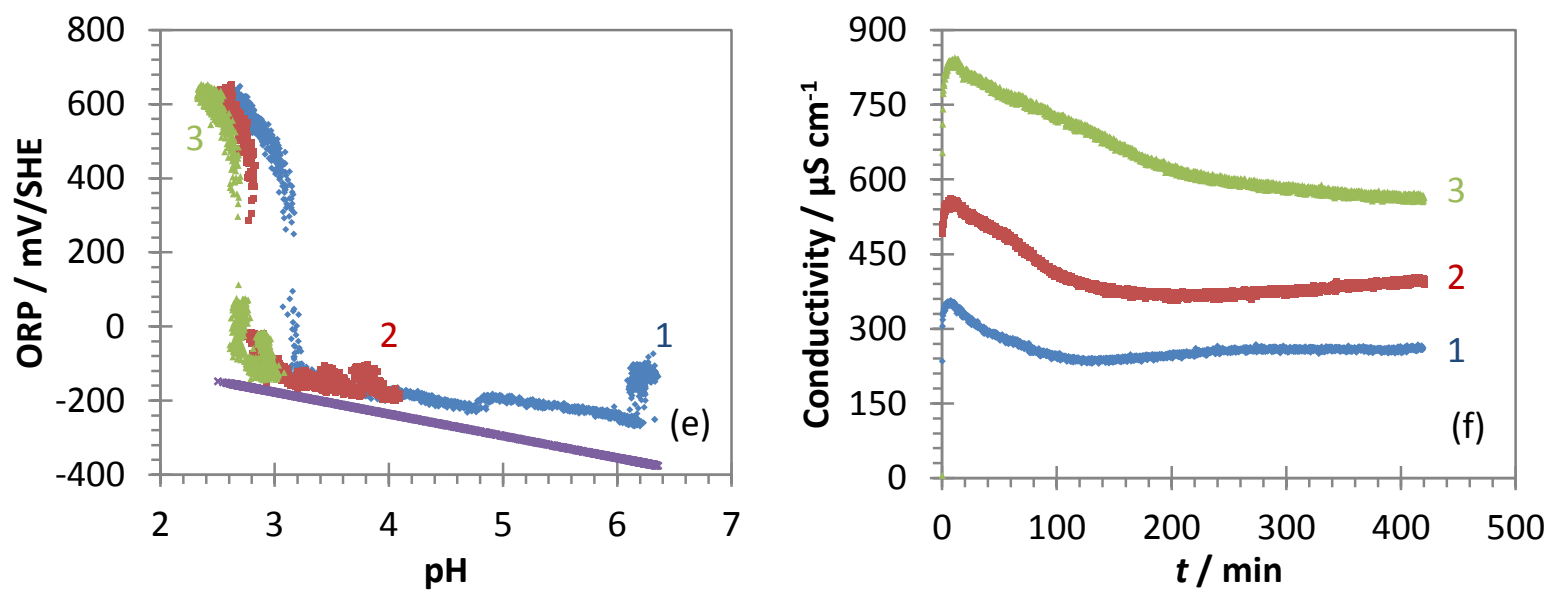

847 $\diamond(1)=850 \mathrm{mg}$ PLA, $\square(2)=1700 \mathrm{mg}$ PLA,$\Delta(3)=3400 \mathrm{mg}$ PLA,$\bullet=$ blank,$\times=\mathrm{H}^{+} / \mathrm{H}_{2}$ redox couple

849 Fig. 7 Influence of PLA content on HCA dechlorination in the Pd-mZVI/PLA/HCA/ $\mathrm{H}_{2} \mathrm{O}$ system. (a) Evolution 850 of HCA concentration with time, (b) Evolution of $\mathrm{pH}$ with time, (c) Evolution of PCE concentration with time,

851 (d) Evolution of ORP with time, (e) Evolution of ORP with pH, (f) Evolution of conductivity with time. 852 Experimental conditions: $[\mathrm{HCA}]_{0}=10 \mathrm{mg} \mathrm{L}^{-1}, m_{\mathrm{Pd}-\mathrm{mZVI}}=600 \mathrm{mg}, T=25{ }^{\circ} \mathrm{C}$. Error bars in parts a and c represent 853 standard deviation for $n=2$ 


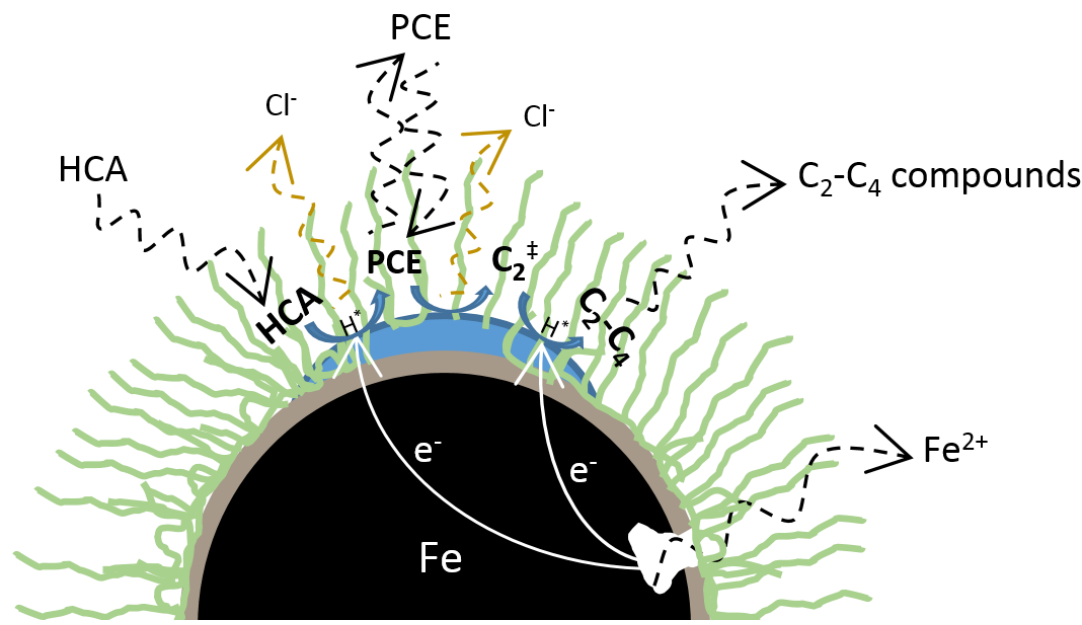

855 Fig. 8 Schematic illustration of reductive HCA dechlorination in the Pd-mZVI/PLA/HCA/ $\mathrm{H}_{2} \mathrm{O}$ system.

856 Reactions proposed in Fig. 3 (production of atomic hydrogen $\mathrm{H}^{*}$ ) and in this figure (HCA dechlorination) may occur simultaneously 